Estefanía Sol Blasco DraguN*

Universidad de Buenos Aires (Argentina)

bla.des@tutamail.com

ORCID iD: http://orcid.org/0000-0001-6089-0314

\title{
La nueva visión del territorio mesoamericano y de las ruinas mayas a través de los dibujos del artista inglés Frederick Catherwood
}

\author{
The new view of Mesoamerican land and \\ the Maya ruins through the drawings of the \\ English artist Frederick Catherwood
}

\begin{abstract}
Resumen: El presente trabajo se propone indagar acerca de la construcción de una nueva visión sobre Mesoamérica a partir de las imágenes producidas por el artista ingles Frederick Catherwood durante su viaje por las tierras centroamericanas a mediados del siglo XIX, en compañía de John Lloyd Stephens. A través del recorrido por la biografía del artista, recuperando la importancia de los viajes y sus relatos desde los primeros contactos entre Europa y América, y revisando el viaje realizado por estos dos personajes, nos centraremos en el análisis de las imágenes publicadas en 1844 bajo el titulo Views of Ancient Monuments in Central América, Chiapas and Yucatán. Con este trabajo buscamos recuperar la importancia de este artista en la historia de los contactos entre Europa y América y en la posterior exploración de los territorios americanos a partir de nuevos paradigmas que otorgaron mayor valor a la antigüedad americana.
\end{abstract}

Palabras clave: viajes, relatos de viaje, siglo XIX, imágenes

\begin{abstract}
The present work intends to investigate the construction of a new vision about Mesoamerica from the images produced by the English artist Frederick Catherwood during his trip through the Central American lands in the middle of the 19th century, accompanied by John Lloyd Stephens. Through the artist's biography, recovering the importance of travel and his writings from the first contacts between Europe and America, and reviewing the journey made by these two characters, we will focus on the analysis of the images published in 1844 under the title of Views of Ancient Monuments in Central America, Chiapas and Yucatan. With this work we seek to recover the importance of this artist in the history of the contacts between Europe and America and the subsequent exploration of the American territories from new paradigms that gave more value to American antiquity.
\end{abstract}

Key Words: travels, travel writing, XIX century, images \footnotetext{
Universidad de Buenos Aires. Docente de artes e investigadora independiente. Actualmente realizando trabajos de investigación como adscripta a la Cátedra de Historia del Arte Precolombino, Facultad de Filosofía y Letras (UBA).

Áreas de Investigación: Historia y teoría del arte precolombino, arte mesoamericano, iconografía, materialidad.
}

Licenciada y Profesora en Artes (Orientación Artes Plásticas) por la Facultad de Filosofía y Letras,

ORCID iD: http://orcid.org/0000-0001-6089-0314

Recibido: 01/10/2017 - Aceptado: 09/01/2018 


\section{Introducción}

Los viajes y sus relatos han marcado la historia de América, y especialmente la historia de sus contactos con el Viejo Mundo. Ambos se han condicionado, alimentado, cuestionado y reformulado los unos a los otros en una dialéctica que se despliega desde el inicio de la historia moderna del continente americano. Dentro de estas relaciones, tan ricas como complejas, entre viajes y relatos, el papel fundamental desempeñado por las imágenes muchas veces ha quedado en segundo plano. Sin embargo, es evidente que éstas agregaron sentidos nuevos, reforzaron y ampliaron las narraciones escritas, incluso muchas veces contradiciéndolas, y es por ello que constituyen un universo simbólico fundamental para comprender las relaciones entre viajes y relatos, entre realidades y ficciones, entre pruebas de veracidad y construcciones de fantasía.

El presente trabajo pretende indagar acerca del modo en que Frederick Catherwood contribuyó a la construcción de una nueva imagen de Mesoamérica, a través de los dibujos que realizó durante su viaje por las tierras centroamericanas a mediados del siglo XIX. Este dibujante y arquitecto inglés recorrió, junto al abogado estadounidense John Lloyd Stephens, los territorios comprendidos entre Honduras y la península de Yucatán, plasmando los lugares y las ruinas visitados en una nutrida producción de dibujos que luego serían grabados para acompañar los famosos libros escritos por John Stephens, titulados Incidents of Travel in Central América, Chiapas and Yucatán, e Incidents of Travel in Yucatán, publicados por primera vez en los Estados Unidos en $1841 \mathrm{y}$ 1843 respectivamente. Luego del éxito obtenido a través de estos volúmenes, Frederick Catherwood decidió editar en Londres, y de forma individual, un compendio de veintiséis de sus grabados, acompañados de comentarios de su autoría, al cual tituló Views of Ancient Monuments in Central América, Chiapas and Yucatán. Este último es el objeto de indagación puntual que analizaremos a continuación.

Iniciaremos el presente artículo destacando algunos datos biográficos del autor, para comprender el modo en el cual tanto su formación, que supone una tradición impregnada del romanticismo y el neoclasicismo imperantes en la Inglaterra de la época, cómo la posibilidad de viajar a través de Europa, Egipto y el Cercano Oriente, influyeron y condicionaron tanto la realización de su viaje a Centroamérica como las imágenes que allí produjo. Luego mencionaremos brevemente algunos de los datos más relevantes respecto de los viajes y sus relatos, para comprender sus características e importancia 
a mediados del siglo XIX, tanto en cuanto al estatuto científico de los datos presentados como a su interés editorial. Aquí nos detendremos especialmente en la importancia que revisten las imágenes en este tipo de literatura en particular. Relataremos brevemente el viaje realizado por Catherwood y Stephens al territorio mesoamericano y las condiciones concretas en las cuales el artista realizó sus dibujos. Finalmente analizaremos algunas de las imágenes que componen las Views of Ancient Monuments in Central América, Chiapas and Yucatán, seleccionadas por considerarlas ilustrativas del compendio general. Junto a ellas expondremos algunos fragmentos de los comentarios escritos por Catherwood, que ilustran las complejas relaciones entre imagen y texto.

Esperamos con esto demostrar el modo en que este artista, de formación inglesa, llevando consigo los paradigmas estéticos europeos, y sumando a esto su experiencia en el registro de sitios con ruinas de antiguas civilizaciones europeas, egipcias y del Cercano Oriente, construyó a través de sus imágenes una nueva visión en la cual los antiguos habitantes de América y sus producciones materiales tendrían una identidad y valor propios, visión que se difundió por los Estados Unidos y también por Europa, y que influyó en los estudios posteriores sobre la antigüedad mesoamericana.

\section{Formación y primeros viajes de Catherwood}

Frederick Catherwood nació el 27 de febrero de 1799 en Hoxton, Londres, en el seno de una familia burguesa ${ }^{1}$. De joven inició sus estudios junto al arquitecto Michael Meredith, quien lo empleó en su estudio y lo tomó como aprendiz, experiencia que marcó el futuro de Catherwood como arquitecto. A partir del trabajo en el estudio de Meredith, el joven Frederick pudo profundizar cada vez más en el mundo del dibujo arquitectónico, al ir plasmando en el papel los edificios londinenses. Estos dibujos se vendían con bastante éxito en aquellas épocas, siendo adquiridos tanto por los propios londinenses como por los viajeros europeos y estadounidenses que pasaban por la capital inglesa. La destreza como dibujante de Catherwood fue alentada por su familia y amigos, lo cual lo impulsó a inscribirse en varios cursos

\footnotetext{
1 Para una biografía completa de F. Catherwood ver Fabio Bourbon, The lost cities of the Mayas: The Life, Art, and Discoveries of Frederick Catherwood, (México: Artes de México, 1999) y Víctor Von Hagen, F. Catherwood, ArchitectExplorer of Two Worlds, (Barre: Barre Publishers, 1968).
} 
dictados por la Royal Academy of Arts de Londres. Allí estudiaría con grandes maestros de la época, como por ejemplo Henry Fuseli (1741-1825), y John Soane (1753-1837). Tanto en Fuseli, que tenía una fuerte tendencia hacia temas inquietantes y atmósferas oníricas, como en Soane, quien acercaría a Catherwood la obra del dibujante italiano Giovanni Battista Piranesi (17201778), se puede notar la huella del romanticismo que, para inicios del siglo XIX ya había arraigado en Inglaterra. Dentro de esta tendencia se destacaba especialmente el interés tanto por la naturaleza como por el estudio de antiguos sitios y arquitecturas ${ }^{2}$. El romanticismo concebía tanto la naturaleza como las ruinas como motivo de inspiración poética, y luego les otorgaría un lugar preponderante como objeto de curiosidad académica.

Al observar las obras de Fuseli y de Piranesi es posible comprender la forma en que Catherwood construirá posteriormente sus imágenes: por ejemplo en el dibujo The Artist in Despair over the Grandeur of Antique Remains of 1778-1780, se puede observar cómo Fuseli retrata aquel artista sosteniendo con su mano derecha su cabeza mientras apoya la izquierda en el pie de una escultura colosal de Constantino en Roma del siglo cuarto. La actitud que muestra este personaje ilustra el sentimiento del propio Fuseli, y luego también de Catherwood ante los monumentos de la antigüedad: tanto el desafío de capturar la fuerza del trabajo de los antiguos como la sensación de ser superado artísticamente por el pasado eran denominador común en la actitud de los artistas del siglo XVIII ante aquellas obras. Así como en Europa, las vistas de ruinas americanas darán a Catherwood la oportunidad de reflexionar acerca del tiempo y la civilización ${ }^{3}$.

Por otro lado, las imágenes de Piranesi eran muy populares en la época, y circularon ampliamente por Europa a partir de su adquisición especialmente por parte de las personas que realizaban el Grand Tour. El atractivo de las imágenes de Piranesi provenía de las vistas de Roma que fundían la capital italiana con su pasado glorioso, a través de las ruinas que se convertían en visiones misteriosas. El artista italiano había sido testigo de un momento crucial en las excavaciones en el foro romano, en el cual los nuevos descubrimientos sacaban a la luz las formas arquitectónicas que serían retomadas por el neoclasicismo. Esta difusión de las obras de Piranesi demuestra el modo en que fue esencial durante el siglo XVIII la producción de imágenes sobre sitios

\footnotetext{
2 Tripp Evans, Romancing the Maya: Mexican Antiquity in the American Imagination, 1820-1915 (Austin: Univesity of Texas Press, 2004), 49-53.

3 Joanne Pillsbury (ed.), Past presented: archaeological illustration and the ancient Americas, (Washington D.C: Dumbarton Oaks, Harvard Univ. Press, 2012), 16.
} 
y ruinas, ya que poca gente podía viajar para tener acceso a ellos, y aquella que lograba deseaba tener un registro tangible de aquella hazaña.

Inspirado posiblemente por las imágenes de Piranesi, Catherwood inició su primer viaje fuera de Inglaterra, que lo llevaría en primera instancia a Roma, atraído por aquellas vistas de la ciudad y sus ruinas. Desde allí se trasladaría por un breve lapso de tiempo a Egipto, para luego arribar a Grecia, la otra gran ciudad europea que mostraba un glorioso pasado a través de sus antiguos edificios monumentales. Luego de varias idas y vueltas, recorriendo y dibujando aquellos paisajes que se abrían ante su vista y adquiriendo de este modo la experiencia necesaria, Catherwood se unió como dibujante a la expedición de Robert Hay a Egipto en el año 1829. Su trabajo consistió en dibujar las pirámides de Giza, los colosos de Memnon, entre muchas otras ruinas, aplicando para ello un laborioso trabajo de medición, utilizando la cámara lúcida, construyendo estructuras para lograr captar detalles y tener una dimensión más aproximada de las estructuras, todo ello para lograr la mayor precisión posible en sus dibujos.

Finalizado su trabajo en la expedición de Robert Hay, Catherwood continuó recorriendo Egipto y el Cercano Oriente bajo la protección de Mohammed Alí, pasha de Egipto, para quien dio clases de arquitectura y reconstruyó algunas mezquitas en El Cairo. Desde allí pudo recorrer sitios como Cartago, Algiers, Arabia Pétrea, Jerusalén, Jordán, Líbano, Heliópolis, Damasco y Palmira. En su extenso trayecto, Catherwood optó siempre por mezclarse con los lugareños, indagar sus costumbres, adoptar sus vestimentas, e incluso aprender lo mejor posible sus idiomas, llegando a hablar italiano, griego y árabe de manera fluida. Estas experiencias le dieron la oportunidad de acceder y entender sistemas y formas arquitectónicas diferentes de las técnicas constructivas y decorativas inglesas que conocía previamente, ampliando su universo visual y conceptual, lo cual resultaría fundamental para comprender y valorar los estilos de construcción que vería luego en su viaje por América. Algunos de los trabajos realizados en esta etapa fueron publicados como ilustraciones de libros, o circularon como mapas y vistas de aquellas tierras, las cuales eran consideradas exóticas en esas épocas.

Esta posibilidad de formar parte de grandes expediciones como dibujante era parte de una actitud compartida en la época, en la cual el interés por las antigüedades estaba transformándose en una actividad cada vez más académica. La larga tradición de los anticuarios, que había iniciado en Europa durante el renacimiento, estaba combinándose con los nuevos métodos de las 
ciencias naturales. A su vez crecía el interés por los rastros de la antigüedad, impulsado por la aspiración de abarcar a la humanidad dentro de un mismo hilo histórico. De esa forma, mientras los objetos naturales que podrían arrojar luz sobre el pasado, como piedras, huesos y fósiles, fueron de poca utilidad sin los métodos científicos de datación, por el contrario, los artefactos (obras de arte visual, artesanía y cultura material) fueron evidencia histórica más confiable, ya que a través de sus inscripciones, estilos y técnicas podrían ser sometidos a dataciones e interpretaciones posteriores ${ }^{4}$. Esta presencia del interés anticuario heredado de los siglos anteriores, irá configurando el nuevo paradigma científico, especialmente el de la futura antropología, que otorgará una importancia fundamental a la representación de las ruinas y los objetos del pasado. En esta representación anticuaria de inicios del siglo XIX es donde Catherwood encontrará la posibilidad de destacarse como artista viajero, y lo perpetuarán en la tradición de los viajes exploratorios.

\section{Los viajes y sus relatos: camino a América}

Para comprender la importancia de las imágenes de Catherwood en la configuración del territorio mesoamericano y cómo estas se insertan en una larga tradición de ilustraciones que marcaron relaciones de influencias mutuas entre el imaginario europeo y la realidad americana es necesario considerar el valor y la función de los relatos de viajes en esta historia de contactos.

Desde los primeros testimonios de Cristóbal Colón podemos observar incluso cómo esta literatura estuvo en las bases de su exploración del nuevo continente. Desde sus inicios, los relatos de viajes marcaron relaciones imaginarias entre América y Asia por un lado, y entre América y los relatos e imágenes fantásticas de la tradición antigua y medieval por el otro ${ }^{5}$. Entre estos textos se destacan los escritos de Marco Polo y el Libro de las Maravillas del Mundo de Sir John Mandeville, en el cual se traza una estrecha relación entre imagen y texto, característica que se mantendrá posteriormente en este

\footnotetext{
4 Giovanna Ceserani, “Antiquarian Transformations in Eighteenth-Century Europe”, en Alain Schnapp (ed.), World Antiquarianism: Comparative Perspectives (Los Angeles: The Getty Research Institute, 2013), 317.

5 Véase Helga Von Kugelgen, “El indio: ¿Bárbaro y/o buen salvaje?”, en AA.VV., La imagen del indio en la. Europa moderna (Sevilla: Consejo Superior de Investigaciones Científicas, 1990); y Jean Paul Duviols, "Visión primitiva del Nuevo Mundo según los viajeros europeos”, en 1492 Dos mundos, paralelismos y convergencias. XII Coloquio Internacional de Historia del Arte, (México: UNAM, 1991).
} 
tipo de escritos. Las imágenes, quizás aun más que los relatos, tendrán un rol fundamental en el imaginario que los europeos proyectarán sobre nuestro continente.

Los viajes realizados por Cristóbal Colón iniciaron una larga historia de exploraciones hacia el continente americano, que se sucedieron durante los siglos XVI y XVII, ligados a motivaciones religiosas, económicas y políticas.

En este periodo los viajes estarían avocados al descubrimiento de nuevas tierras y recursos explotables, combinados con las estrategias tendidas luego para el establecimiento de las colonias y la apropiación de los recursos americanos. Esta primera etapa de conquista activa, violenta, de apropiación de recursos dará paso en el siglo siguiente a un modo distinto de entender los viajes y de trazar relaciones con lo no europeo.

Los viajes exploratorios fueron incrementándose a partir del siglo XVIII, gracias a los conocimientos acumulados y a la experiencia e intereses crecientes, tanto de los viajeros como de aquellos individuos e instituciones que los financiaban. Para esta época los viajes se convirtieron en una experiencia clave en la adquisición de conocimiento, de fundamental valor en la constitución de las disciplinas científicas modernas, imbricadas en el dominio político y la explotación económica de los territorios americanos. Estas expediciones político-científicas cambiaron el sentido de los viajes, los cuales pasaron a ser viajes de conquista, pero esta vez de una conquista pasiva, por adquisición de conocimiento. Según Mary Louise Pratt ${ }^{6}$, el descubrimiento consistía entonces en un gesto que convertía los conocimientos locales en conocimientos europeos nacionales y continentales, es decir, por un lado como conocimiento europeo sobre lo americano, y por otro como competencia entre las distintas potencias europeas. Este nuevo modo de conquista estaba centrado en la experiencia pasiva de mirar, que llevaría consigo la idea de renombrar, redescubrir y catalogar a la naturaleza. A su vez desatarían toda una industria avocada al desarrollo de la medición, la conservación y el traslado de los especímenes hallados. El nacimiento de la ciencia moderna estaría por lo tanto ligada a la idea de conquista en el plano ideológico, y a los métodos recolección y clasificación, heredados en parte de los anticuarios y reformulados por otro por los métodos de las ciencias naturales. Se trazarían de este modo lazos profundos entre la historia del arte, la arqueología y los estudios sobre patrimonio, sobre este nuevo modelo de investigaciones 
profesionalizadas e institucionalizadas, en manos de científicos, y ya no de anticuarios como lo había sido desde el renacimiento en adelante ${ }^{7}$.

Estas relaciones harían que se fusione en muchos casos la figura del viajero y la del científico, dado el aporte que los primeros realizarían al campo de las nacientes ciencias, y por la condición experimental de la nueva generación de científicos que viajaban a recolectar material y hacer sus observaciones in situ. Las imágenes realizadas durante los viajes fueron investidas de un valor epistemológico fundamental, tanto aquellas producidas por dibujantes especializados como las imágenes de vistas y panoramas pintorescos que incluían monumentos de la antigüedad. El coleccionismo, de objetos e imágenes, se convirtió así en la base de la historia tanto de las ciencias naturales como de la arqueología, en cuanto permitió establecer modelos abarcadores que contuvieran los distintos conjuntos de especímenes, pero también al establecer la forma de recolectar y presentar aquellos especímenes en las diversas publicaciones ${ }^{8}$.

De esta forma los datos recolectados y el material producido durante los viajes fueron el material que luego se clasificó y sobre el cual se interpretó el mundo. En gran parte por la necesidad de contextualizar los objetos recolectados durante los viajes es, por ejemplo, que comenzaron a proponerse cronologías que sentarían las bases para los métodos arqueológicos posteriores. Dentro de este paradigma de observación y clasificación de datos, cumplirán un rol sustancial los elementos de visión y de medición, por lo que es posible pensar en la relación establecida entre la necesidad de viajar a distancia para conocer y los instrumentos de visión que justamente lo que permiten es acortar la distancia entre el observador y lo observado?. De este modo, los viajes hicieron que comenzara a superponerse todo lo conocido e imaginado por Europa con lo contrastado a partir de las expediciones, poniendo a prueba los modelos construidos respecto de los territorios y sujetos que los poblaban. Estas expediciones, entre las cuales podemos citar las comandadas por James Cook, Charles de La Condamine, Louis-Antoine de Bougainville y Alejandro Malaspina, fueron acompañados por artistas o sujetos capacitados para realizar registros gráficos de lo observado en el continente. El grabado -realizado a partir de los dibujos hechos por aquellos artistas- y la pintura serán soportes privilegiados para acompañar las exploraciones y mostrar datos

\footnotetext{
Ceserani, "Antiquarian Transformations in Eighteenth-Century Europe”, 333.

8 Pillsbury, Past presented: archaeological illustration and the ancient Americas, 12.

9 Marta Penhos, Ver, conocer, dominar. Imágenes de Sudamérica a fines del siglo XVIII, (Buenos Aires: Siglo XXI Editores, 2005), 16-17.
} 
que se presentaban a la vista de una forma más directa e inmediata que la descripción, y serán consideradas poseedoras de un alto grado de objetividad.

Estos viajes, que habían sido motivados en sus inicios por relatos de viaje fantásticos, fueron resultando paulatinamente en generadores de nuevas literaturas de viajes, pero ligadas ahora a la necesidad de transmitir aquellos descubrimientos que se iban realizando. Los relatos de viaje fueron entonces depositarios de ciertas exigencias de veracidad, de acuerdo a los paradigmas científicos de la época, así como también de las expectativas de los lectores respecto de aventuras en sitios lejanos. Estas características se tradujeron en la presencia de descripciones con detalles precisos sobre las escenas, personajes, lugares y objetos vistos, mezcladas con las aventuras vividas por el narrador. Tanto estas experiencias como la fidelidad de los datos eran respaldadas, en primera instancia por la figura del autor, que aparecía casi siempre en la portada del libro, constituyéndose como garante de un "pacto autobiográfico", por el cual el lector admitía la identidad entre el autor, el narrador y el personaje (el viajero), asegurando así la veracidad de lo narrado: "La función central de todo narrador de un relato de viaje, su deber implícito, es informar, y, de acuerdo a los pactos que rigen el género, que tal información sea veraz, es decir, fiable" $"$.

Esta presencia del autor refuerza entonces el carácter científico y al mismo tiempo el carácter autobiográfico, generando una tensión entre el sujeto observador y el objeto observado. Según Tzvezan Todorov

La primera característica importante del relato de viaje (...) es una cierta tensión (o cierto equilibrio) entre el sujeto observador y el objeto observado. Esto que designa, a su manera, esa denominación, "relato de viaje": relato, es decir narración personal y no descripción objetiva; pero también viaje, un marco, pues, y unas circunstancias exteriores al sujeto. Si sólo figura en su lugar uno de los dos ingredientes, nos salimos del género en cuestión para meternos en otro [...]. El límite, por un lado, es la ciencia; por el otro, la autobiografía; el relato de viaje vive de la interpenetración de los $\operatorname{dos}^{11}$.

Es esta la principal relación entre el relato de viaje y la ciencia etnográfica: la existencia de un desplazamiento en el espacio, la hipervaloración de la

\footnotetext{
${ }^{10}$ Beatriz Colombi, “El Viaje y su Relato”, Latinoamérica. Revista de Estudios Latinoamericanos, nº 43 (2006): 24.

11 Tzvetan Todorov, Las morales de la historia, (Barcelona: Paidós, 1993), 99.
} 
imparcialidad del testigo, y un componente enunciativo explícito definido por el carácter autobiográfico del discurso.

El otro recurso fundamental por el cual se asegura la veracidad en los relatos de viaje es la presencia casi inevitable de las imágenes, ya que éstas se constituyen en pruebas visuales de lo narrado, llegando a veces a salvar la inefabilidad de ciertas situaciones mostrando aquello que es imposible narrar, porque excede a la palabra: "el discurso escrito representa en términos evocativos experiencias de orden visual, pero por su propia lógica y funcionamiento, no las provoca, en tanto que las imágenes son representaciones de datos de la realidad visual que además se presentan como nuevas experiencias visuales"12. A esto debemos sumar el interés que la presencia de las imágenes despertaba y aun hoy despierta en los lectores.

Podemos pensar, siguiendo a Carolina Depetris ${ }^{13}$, que esta inclusión de las imágenes como elementos constituyentes de los relatos de viajes es una de las marcas de posmodernidad presente en este tipo de literatura moderna, caracterizada por el solapamiento de distintos tipos de discurso -incluyendo a las imágenes como un tipo particular de discurso visual- y la infiltración de características literarias en los relatos de viajes. Se hallan en estos relatos imágenes de diversa índole, principalmente científicas, del tipo taxonómico por ejemplo, pero también se incluyen imágenes que agregan elementos narrativos. Siguiendo a Marta Penhos consideramos que el afán por incluir imágenes ya sea que estas fuesen producidas in situ o elaboradas posteriormente -o incluso reutilizadas de otros textos-, es prueba de la necesidad de reducir la experiencia del desplazamiento en tiempo y espacio, para subsumirla a elementos que hicieran más accesible su comprensión y transmisión. Sin embargo, más allá de que las imágenes hayan sido depositarias de una confianza en el sentido de la vista como vía principal de conocimiento del mundo fenoménico, por otra parte poseen una opacidad respecto de lo que representan, que habilita a identificar en ellas las tensiones entre verdad y verosimilitud, entre objetividad e invención, en definitiva entre plasmación fiel de la realidad e intervención de la subjetividad del viajero ${ }^{14}$.

\footnotetext{
12 Penhos, Ver, conocer, dominar. Imágenes de Sudamérica a fines del siglo XVIII, 23.

13 Carolina Depetris, "El relato de viaje moderno: ¿posmodernidad escondida?", Cuadernos del CILHA 14, n 19 (2013): 109-126.

14 Marta Penhos, "Viajes, viajeros e imágenes: una relación necesaria". En Travesías de la imagen. Historias del arte en la Argentina, eds. Baldasarre, María Isabel y Silvia Dolinko, vol. 2 (Buenos Aires: Centro Argentino de Investigadores de Arte/ EDUNTREF, Archivos del CAIA IV, 2013).
} 
Los relatos de las experiencias de viaje que transitan el pasaje hacia los modelos de objetividad modernos en el siglo XIX, se manifestarán entonces en literaturas que no serán solamente valoradas como guía de informaciones utilitarias, sino que en muchos casos privilegiarán las peripecias sufridas por el narrador/viajero, desplegando sus impresiones personales, haciendo estas narraciones más accesibles y atractivas para el público general. De esta manera se evidencia la coexistencia de una sensibilidad racionalista con otra romántica, cuyo punto de inflexión puede marcarse a partir de la figura de Alexander Von Humboldt quien, de alguna forma, unirá estas dos características del relato.

Von Humboldt recorrió el continente americano desde México hasta Perú por el interior del territorio, investigando todos los aspectos del territorio, abarcando desde la llamada Cosmografía (como ciencia natural que unía conocimientos de orografía, hidrografía, geografía, astronomía) hasta las culturas americanas. Su modo de abordaje del conocimiento era holístico, pero a su vez detallado en la observación, medición y clasificación de todo lo estudiado. Sus escritos, si bien en general tienen un estricto carácter científico, contienen percepciones personales de carácter más bien subjetivo, apelando al lector con un lenguaje accesible de tinte heroico. Su objetivo era tener como espectadores no sólo al círculo de científicos, sino poder llevar el conocimiento al público en general. Incluso se puede observar en algunos textos de carácter más íntimo, el modo en que Humboldt alude a su propio sufrimiento físico, lo cual es un indicador de la estrecha relación que mantenía como sujeto con el objeto de su investigación: "Sin duda, las obras de Humboldt también han influido ampliamente en la concepción de mundo americano y de esta manera han contribuido a modificar o redefinir la imagen que se tenía del nuevo mundo en la Europa del siglo XIX, muy distinta a la que se tenía en el siglo XVIII" $"$.

Este científico viajero marcó un hito fundamental en la historia de los viajes y sus narraciones, en especial en relación al continente americano, y es un claro ejemplo de la importancia de los viajes como hacedores de significados e interpretaciones, en la medida en que 'inventaron' lugares, individuos, grupos y propusieron relaciones entre occidente y el resto del mundo ${ }^{16}$. A partir de sus escritos, Humboldt impulsó de manera directa o indirecta a varias generaciones de artistas, científicos y viajeros a interesarse por el continente

\footnotetext{
15 Sandra Rebok, "La expedición americana de Alexander Von Humboldt y su contribución a la ciencia del siglo XIX", Bulletin de l'Institu Francais d'Etudes Andines 32, n³ (2003): 449.

16 Véase Penhos, "Viajes, viajeros e imágenes: una relación necesaria".
} 
americano, recorrerlo, observarlo, medirlo, disfrutar y tratar de interpretar esa naturaleza y habitantes tan distintos a lo conocido anteriormente. Humboldt propondrá un nuevo modo de explorar América, que será apropiado luego por científicos y artistas que centrarán su atención especialmente en los restos de la antigüedad americana.

\section{El descubrimiento y la construcción de Mesoamérica}

La larga tradición de exploraciones por el continente americano y la región mesoamericana en particular, se remonta a las incursiones por parte de la Corona española y el establecimiento de su dominio sobre los pueblos descubiertos. Esto respondió en sus inicios a una visión en la cual se contradicen y complementan los deseos de apropiación de tierras y bienes materiales, con los ideales cristianos que movilizaron a gran número de misioneros a intentar lograr la eterna salvación a través de la conversión de los habitantes nativos del Nuevo Mundo. Esta tensión marcó las relaciones entre la Corona y la iglesia, y entre las posturas de religiosos y autoridades tanto coloniales como peninsulares.

La llegada de los primeros españoles al territorio mesoamericano tuvo lugar en las costas de la península yucateca, la cual actuó como puerta de entrada de Hernán Cortés, quien, informado de la existencia de la floreciente civilización mexica tierra adentro, dejó atrás aquel territorio para establecer el centro del dominio español en el centro del territorio mexicano. Fue tarea entonces del adelantado Francisco de Montejo, y luego su hijo y sobrino, la de conquistar el territorio yucateco, proceso que se extendió durante un lapso de veinte años, dada la hostilidad de los pueblos mayas. Para ese entonces ya habían llegado a la península grupos de misioneros, especialmente dominicos y franciscanos. Los misioneros, movidos por el carácter salvífico de la religión cristiana, y su concepción de la historia como un plan providencial de redención que era menester completar a través de la labor misionera en los cuatro puntos del mundo, llevaron adelante la ardua tarea de evangelizar a aquellos pueblos, cambiando varias veces de estrategia hasta lograr su cometido. En parte para poder llevar adelante estas estrategias y en parte por su formación humanista, los misioneros se ocuparon de generar los registros etnográficos más importantes de los tiempos de la conquista: a la vez que 
destruían gran parte de los elementos culturales autóctonos buscando extirpar las idolatrías, no dejaron de sorprenderse por los hallazgos culturales de aquellos pueblos. Escribieron entonces sobre sus costumbres, describieron sus objetos, e intentaron dejar registro de las lenguas en que hablaban, para lograr comprenderlos y a su vez superponer a esas tradiciones las nuevas doctrinas.

En este contexto, y en medio del trabajo de conquista emprendido por Montejo, llegó a Yucatán en 1549 el franciscano Diego de Landa, quien sería primer obispo de Yucatán. Su registro escrito sobre el pueblo maya es hoy en día el texto etnográfico colonial más importante para los investigadores de esta cultura. Landa no sólo registró la historia de los mayas y de su conquista, sino que tomó la iniciativa de su predecesor para registrar la lengua de aquel pueblo. En sus escritos se evidencia la tensión entre la labor misionera, y los intereses de los conquistadores:

"El que más supo [de las lenguas mayas] fue fray Luis de Villalpando, que comenzó a saberla por señas y pedrezuelas y la redujo a alguna manera de arte y escribió una doctrina cristiana en aquella lengua, aunque había muchos estorbos por parte de los españoles que eran absolutos señores y querían que se hiciese todo enderezado a su ganancia y sus tributos, y de parte de los indios que procuraban estarse en sus idolatrías y borracheras; principalmente era de gran trabajo por estar tan derramados por los montes. ${ }^{17}$

Los misioneros y los colonizadores configurarían en sus disputas la imagen sobre el hombre americano que sentaría sus bases en América y tendría sus ecos en el Viejo Continente. Ya fuese en los argumentos de los conquistadores que buscaban extraer riquezas esclavizando a los indígenas y por tanto los retrataban como seres corruptos y salvajes, o en la postura de los neófitos que, buscando evangelizarlos, proclamaban que los indígenas eran seres nobles, con un sentido intrínseco de la divinidad, cuya alma era pasible de ser convertida al cristianismo, y por tanto era menester salvarlos de los tratamientos brutales por parte de los conquistadores, los indígenas, tanto malos como buenos salvajes, fueron recluidos desde el primer momento al lugar de seres inferiores. Esta disputa, iniciada en América, fue aprovechada en Europa por las rivalidades entre las naciones; los españoles fueron señalados como conquistadores despiadados y otras naciones buscaron presentarse como más civilizados y capaces de administrar las nuevas tierras. 
De esta forma la imagen que se consolidó de los habitantes de América como seres inferiores, imposibilitados incluso de poder hacer uso debido de sus propios recursos, funcionó como argumento de ambas orillas para justificar la conquista espiritual y la apropiación material de lo americano. Incluso en los escritos de Diego de Landa, quien estaba asombrado por la construcción de ciudades como Uxmal, Chichén Itzá y Mayapán, asegurando que aquellas habían sido construidas por los antepasados de los mayas yucatecos, el acento recae en el estado decadente de aquel pueblo:

"Porque decir que los hayan edificado otras naciones sujetando a los indios, no es así, por las señales que hay de haber sido edificados por gente indiana y desnuda (...). Bien sea, que si lo fueron, era gente de más ser que los de ahora y muy de mayores cuerpos y fuerzas..." 18

Los registros escritos durante la segunda mitad del siglo XVI y el XVII sobre el territorio mesoamericano y sus habitantes, fueron entonces principalmente registros de los conquistadores o de los misioneros, que compartían estos rasgos intentando justificar la conquista. En estos textos la referencia al pasado prehispánico fue especialmente conflictiva, en parte por el temor que suscitaba la posibilidad de regreso a las idolatrías de los americanos, dada la dificultad que significó durante aquel periodo el establecimiento de un control efectivo sobre los indígenas ${ }^{19}$.

Fue recién a mediados del siglo XVIII cuando el impulso del iluminismo llevó a despertar el interés por el conocimiento del territorio americano y los vestigios de las antiguas civilizaciones. Las políticas borbónicas relacionadas con las colonias americanas impulsaron nuevas estrategias de exploración con el fin de extraer riquezas para la corona, generar nuevos mercados y 'proteger las colonias especialmente de la amenaza que representaba Gran Bretaña. A su vez que el carácter ilustrado de los reyes borbónicos contextualizó estas búsquedas en el afán de conocimiento de las colonias, que impulsó las expediciones científicas, y a su vez la solicitud de informes sobre las antigüedades del territorio.

Fue en este contexto que en 1784 el entonces gobernador de Guatemala, don José de Estachería, envió al oficial José Antonio Calderón a realizar un

\footnotetext{
${ }^{18}$ Landa, Relación de las cosas de Yucatán, 188.

19 Pillsbury, Past presented: archaeological illustration and the ancient Americas, 7.
} 
informe sobre el sitio de Palenque, el cual, a diferencia de las ruinas yucatecas, había permanecido oculto hasta 1746, año en que el padre Antonio de Solís descubrió la ciudad. El informe de Calderón resultó demasiado reducido, y la necesidad de obtener una idea clara del aspecto del sitio hizo que enviara al año siguiente al arquitecto Real de la Ciudad de Guatemala, Antonio Bernasconi ${ }^{20}$. Las órdenes dadas a Bernasconi incluían indagar la edad del asentamiento, número de pobladores, origen de sus fundadores, el estilo, medidas y materiales de las construcciones, y las causas de su decadencia, entre otras. El informe de Bernasconi, si bien era más elaborado en cuanto a sus dibujos no fue satisfactorio en cuanto a la información que brindaba. De todos modos, Estachería envió ambos informes, el de Calderón y el de Bernasconi, a España. Estos informes fueron motivo suficiente para que el rey Carlos III solicitara una descripción más detallado del sitio. Para ello fue designado el capitán Antonio del Río, quien en el año 1787 realizó una expedición a Palenque acompañado por el dibujante Ricardo Almendáriz. El informe de Del Rio fue enviado a España, junto con los dibujos y algunas piezas recolectadas durante la expedición, y permanecieron en el Real Gabinete de Historia Natural ${ }^{21}$. Sin embargo el informe de Del Río cobró posteriormente una visibilidad inesperada ya que el escrito llegó de algún modo a Londres, junto a otro texto, titulado Teatro Crítico de Paul Felix Cabrera, un italiano radicado en Guatemala, que especulaba sobre el origen transatlántico de los pueblos americanos. Ambos manuscritos fueron publicados por Henry Berthoud en 1822 bajo el título Description of the Ruins of an Ancient City, Discovered near Palenque, in the Kingdo of Guatemala, in Spanish America, translated from the Original Manuscript Report of Capitan don Antonio del Rio: followed by Teatro Critico Americano; or, a Critical Investigation and Research into the History of the Americans by doctor Paul Felix Cabrera of the City of New Guatemala. La edición fue acompañada por las 16 láminas dibujadas por Almendáriz, y grabadas por Jean Frederic Waldeck. Este fue el primer texto sobre los mayas que circuló dentro de un público que podríamos considerar hoy en día especializado en cuestiones relativas al estudio del pasado precolombino.

La información que comenzó a circular por Europa estuvo por lo tanto fuertemente influenciada por el texto de Cabrera, que tenía una extensión cuatro veces mayor al informe de Del Río. Incluso en este último, tanto el texto como las imágenes se hallaban atravesadas por sus conocimientos previos, ajenos a la realidad americana, que llevaron por ejemplo a dibujar

\footnotetext{
${ }^{20}$ Claude Baudez y Sidney Picasso, Lost cities of the Maya (Londres: Thames \& Hudson, 1992), 34.

${ }^{21}$ Robert Brunhouse, En busca de los Mayas: Los primeros arqueólogos (México: FCE, 2013), 14-19.
} 
las construcciones mayas con reminiscencias góticas, los relieves fueron comprendidos como medallones de gobernantes y soldados portando estandartes, y relacionando algunas figuras con dioses romanos y griegos:

\begin{abstract}
"Sabemos que los romanos representaban a Júpiter coronado de laureles, el rostro presentando una edad madura, con una barba larga y un aspecto terrible y un semblante similar; y de forma similar vemos en estas representaciones, para reflexionar sobre la similitud de costumbres y religión, cómo en sus rasgos particulares las dos cabezas son iguales, con la excepción de aquellas mejoras transmitidas al primer busto por la escultura romana, cuyos principios este pueblo [en Palenque] podría haber obtenido pero imperfectamente... 22 "
\end{abstract}

El interés suscitado por la publicación puede verificarse en la aparición de dos traducciones al alemán en 1823 y 1832 respectivamente, y de algunos pasajes traducidos al francés y publicados la Société de Géographie de París en $1825^{23}$. La edición inglesa tuvo algunas revisiones comentadas, que muestran las especulaciones presentes en la época sobre el origen de las ruinas americanas, como por ejemplo el artículo de 1828 de John Ranking que sostenía que los constructores habían podido ser turcos, mongoles y calmucos, que habrían llegado a aquella región en el pasado ${ }^{24}$.

Pero antes de su publicación el manuscrito de Del Río había llegado a España, despertando el interés de Carlos IV, quien solicitó un nuevo informe, esta vez más abarcador del territorio mexicano en el cual se había reportado la existencia de ruinas. Para ello se designó en 1804 a Guillermo Dupaix, quien llevaría adelante una ambiciosa expedición que abarcaría el territorio comprendido entre el centro y el extremo sur de México. Este comandante, más instruido que los expedicionarios anteriores, tenía instrucciones precisas de recabar información sobre las antigüedades mexicanas. Fue designado también oficialmente el dibujante José Luciano Castañeda, quien estuvo a cargo de realizar el relevo gráfico de la expedición que tuvo lugar entre 1805 y 1808. En el informe de Dupaix se repiten algunas de las especulaciones ya mencionadas: si bien daba un panorama de las características singulares de los

\footnotetext{
22 Antonio del Rio, Description of the Ruins of an Ancient City, Discovered Near Palenque, in the Kingdom of Guatemala, in Spanish America: Translated from the Original Manuscript Report of Captain Don Antonio del Rio: Followed by Teatro Critico Americano; or, A Critical Investigation and Research into the History of the Americans, by Doctor Paul Felix Cabrera, of the City of New Guatemala (Londres: Henry Berthoud ed., 1822), 10. La traducción es de mi autoría.

23 Brunhouse, En busca de los Mayas: Los primeros arqueólogos, 20-21.

${ }^{24}$ John Ranking, "Remarks on the Ruins at Palenque, in Guatemala, and on the Origin of the American Indians", en Quarterly Journal of Science, Literature and Art (1828), 135-154.
} 
rasgos del arte y los símbolos de escritura como diferentes incluso a aquellos que había visto en el centro de México, Dupaix concluía que los habitantes de la región no podían ser descendientes directos de los constructores de Palenque. Aunque descartó en parte las especulaciones sobre la presencia de otros pueblos en el territorio anteriormente, dejó abierta la posibilidad de una influencia transoceánica en la antigua cultura mesoamericana. Al igual que había hecho anteriormente Del Río, Dupaix, recogió varios objetos y declaró que los guardaría como recuerdo de su viaje y como testimonio de la fidelidad de los dibujos realizados por Castañeda ${ }^{25}$. Sin embargo estas imágenes, de manera similar a las de Almendáriz, están teñidas de reminiscencias a las estructuras conocidas del viejo mundo, pero esta vez con rasgos especialmente egipcios. Aquellos eran los parámetros visuales de Viejo Mundo con los cuales les era posible abordar aquellas formas desconocidas.

El informe oficial de Dupaix y los dibujos e Castañeda quedaron un tiempo archivados en el Gabinete de Historia Natural de la capital mexicana, dada la imposibilidad de entregarlo a su solicitante inicial. Tuvieron que terminar tanto las Guerras Napoleónicas como las de la Independencia Mexicana para que el informe llegara luego a manos de Edward King, mejor conocido como Lord Kingsborough. Este anticuario inglés, encargado de compilar y comisionar varios trabajos de investigación en América, editó en la década de 1830 siete volúmenes que compilaban bajo el nombre de Antiquities de México, toda una serie de informes de expediciones, ediciones facsimilares de códices prehispánicos, ensayos, y todo el material que pudo compilar sobre el pasado americano. Dentro de esta publicación y junto con el informe de Dupaix, habían otros textos que ponían nuevamente en cuestión el tema del origen de los americanos y los posibles creadores de las ruinas. Comparando los monumentos de México con los de Egipto, India y el resto del viejo continente, o trazando especulaciones sobre la relación de las lenguas americanas con las de India y África, Kingsborough construía un entramado para sustentar sus propias hipótesis, especialmente el hecho de que los antiguos mesoamericanos eran descendientes de las tribus perdidas de Israel.

Kingsborough empleó a Jean-Fréderic Waldeck, para realizar los grabados de las láminas de Almendáriz y Castañeda para su publicación, que luego impulsarían a este excéntrico artista a viajar a Mesoamérica. Waldeck había decidido realizar un viaje expedicionario respondiendo a la solicitud de la

${ }^{25}$ Dupaix G., "Monuments of New Spain", en Edward Kingsborough, Antiquities of Mexico, (Londres: R, Havell, J.Moyes \& R. Taylor, 1831, vol. VI). 
Societé Géographie de París, que ofrecía un premio de 2400 francos a quien trajese una descripción completa y exacta de las ruinas de Palenque, solicitando a su vez "vistas pintorescas" de las ruinas ${ }^{26}$. En 1832 Waldeck llega a América, pero es recién en 1834 cuando puede iniciar el trabajo exploratorio, que dará como fruto la publicación en 1838 en Paris de Voyage pittoresque et archéologique dans la province d' Yucatan ${ }^{27}$. Si bien obtiene el premio de la Societé Géographie, su trabajo no es considerado de valor científico, sino más bien artístico. Waldeck dedica más que un agradecimiento en la portada a su mecenas Kingsborough: a lo largo de las láminas en las que Waldeck ilustra las ruinas establece como punto de partida comparativo a Oriente, aquel Oriente pensado como recurso estético, que alimenta la imaginación, el misterio y el exotismo durante los siglos XVIII y XIX principalmente ${ }^{28}$.

Por último dentro de los principales viajeros que visitaron la región oriental de Mesoamérica y dejaron registros que hoy en día se contemplan como antecesores de la arqueología en la región, está el trabajo de Juan Galindo. Diplomático de origen Irlandés, Galindo llegó desde Inglaterra a Guatemala en 1825, y se convirtió en poco tiempo en gobernador del Peten. Esta posición lo habilito por un lado a investigar las ruinas de la zona, llegando a Palenque en 1831, y por otro le permitió entablar un diálogo directo con la Société de Géographie de París, y la Royal Geographical Society de Inglaterra. Su postura ante los hallazgos en Palenque y luego su expedición a Copán en 1834, lo llevaron a suponer la importancia de Palenque en épocas remotas como sitio estratégico a nivel comercial, más que una ciudad de características guerreras. También reconoció las semejanzas entre los habitantes de la región y los dibujos de los relieves, especulando, a diferencia de la tendencia europea del momento, que la cultura americana podría haber sido el origen de todas las demás culturas antiguas, aunque se encontrara en un estado de decadencia en aquél momento. Si bien se publicó su nota ante la Société de Géographie en que exponía su deseo de "dar a conocer a Europa nuestros derechos a la consideración" 29 , su informe sobre Copán y su no fue publicado sino hasta el siglo $\mathrm{XX}^{30}$.

\footnotetext{
${ }^{26}$ Para una descripción detallada del viaje de Waldeck ver Carolina Depetris, El héroe involuntario. Fréderic de Waldeck y su viaje por Yucatán (México: UNAM, 2014).

${ }^{27}$ Jean-Frederic Waldeck, Voyage pittoresque et archéologique dans la province d' Yucatan pendant les années 1834 et 1836 (París: Bellizard Dufour et cie, 1838).

28 Para un informe más detallado del orientalismo subyacente en el trabajo de Waldeck ver Carolina Depetris, "El orientalismo como episteme: Frédéric de Waldeck y las ruinas mayas”, en HiN, XI: 21 (2010), 10-23.

29 "Memoire de M. Juan Galindo officier superieur de la republique de l'Amerique centrale, sur les ruines de Palenque" (Bulletin de la Société de géographie de Paris, $\left.\mathrm{n}^{\circ} 18,1832\right), 198$.

30 Juan Galindo, "Description of the ruins of Copán" (Sylvanus Morley, The Inscriptions At Copan, Washington DC: Carnegie Institute, 1920).
} 
Como hemos visto, la relación de Europa y América se basó en una serie de paradigmas sucesivos: durante el siglo XVI la sustentación de un modelo que justificara la conquista, que continuó durante el siglo XVII al afianzarse las relaciones de los colonizadores con la apropiación de tierras. Recién en la segunda mitad del siglo XVIII volvemos a hallar una actitud inquisitiva por parte de Europa respecto de los territorios americanos. Pero ¿Qué fue lo que sucedió para que luego de dos siglos se reavivara el interés por las antigüedades americanas?

Como hemos mencionado, a mediados del siglo XVIII el impulso de las ciencias conllevará la necesidad de generar nuevas expediciones y registros de los territorios coloniales. Siguiendo a Mary Louise Pratt ${ }^{31}$, podemos pensar que esta situación se ve enmarcada en el surgimiento de una nueva "conciencia planetaria" en la cual las potencias europeas buscarán consolidar y extender sus dominios imperiales a través de nuevas estrategias. España por un lado se mostrará más permisiva en cuanto a la llegada de expediciones con miembros de distintos países europeos a sus tierras, anteriormente guardadas con recelo. Sin embargo los registros coloniales continuarán durante un tiempo ocultas a los ojos de los demás países, mostrando la diferencia entre los proyectos científicos, que se proponían como la desinteresada búsqueda de conocimiento y la búsqueda de riquezas que había marcado las conquistas de los siglos anteriores, y donde España aún podía conservar el dominio.

Sin embargo, como hemos mencionado, la publicación a gran escala de los textos resultado de las investigaciones del siglo XVIII, e incluso los textos que comenzaron a considerarse relevantes para la ciencia producidos durante el siglo XVI comenzaron a difundirse recién a partir de 1820. Si tenemos en cuenta que "las transiciones históricas importantes alteran la manera en que la gente escribe porque alteran sus experiencias y, con ello, también la manera de imaginar, sentir y pensar el mundo en el que viven"32, podremos visualizar cómo las independencias latinoamericanas aceleraron estos procesos de exploración sobre América y el surgimiento de la arqueología en la región. Es entonces cuando se produce el acceso por un lado a documentos coloniales celosamente guardados por la administración española, y por otro lado el ingreso de viajeros extranjeros con menos restricciones de las que existían previamente. Quienes comenzaron a arribar a la región generarían publicaciones describiendo las nuevas repúblicas, sus historias, economías,

\footnotetext{
31 Pratt, Ojos imperiales. Literatura de viajes y transculturación.

32 Pratt, Ojos imperiales. Literatura de viajes y transculturación, 26.
} 
población, lenguajes, geografías, recursos naturales y antigüedades. Estos reportes, junto a los textos coloniales recuperados pasaron a conformar el corpus de textos central para el estudio de la antigüedad mesoamericana ${ }^{33}$.

Es en este momento cuando se desarrollará lo que Robert Aguirre ha denominado un imperialismo informal, es decir, una versión más leve de imperialismo que tiene lugar cuando la colonización formal ya no es posible, pero las naciones europeas todavía buscan dominar culturalmente y expandirse económicamente ${ }^{34}$. Los intereses coloniales sobre el área mesoamericana variaron dependiendo de la potencia que disputaba el control, y en este caso la disputa terminará en manos de Gran Bretaña y de la naciente potencia norteamericana. Gran Bretaña por su parte, se volcó a la construcción de una ideología para incorporar América Latina como parte de su imperio internacional, a través del control del capital cultural y la institución de una ideología que estableciera la superioridad cultural y racial británica. En cambio para el caso de Estados Unidos fue completamente distinto: la posibilidad de postular un pasado glorioso para América que los equiparara con las culturas madre europeas (principalmente griega y romana) fue un motor infatigable para todos los proyectos desarrollados luego de los viajes de Stephens y Catherwood a la región ${ }^{35}$. En este contexto el viaje de estos hombres, estadounidense uno, inglés el otro, inaugurará un nuevo paradigma de viajes a Mesoamérica, en el cual será cada vez mayor la presencia norteamericana y su rol de mecenazgo a través de sus instituciones científicas.

Si bien el viaje de Stephens y Catherwood no era aun un proyecto como serían los posteriores, financiados principalmente por institutos y universidades estadounidenses o inglesas, marcan un rumbo claro. Tanto en el modo de registrar las imágenes de Catherwood como la voluntad de Stephens de llevarse piezas de Copan para crear un museo de antigüedades americanas en Nueva York, muestran la importancia de las imágenes, esculturas y los moldes de objetos en este nuevo proyecto, en el cual principalmente los Estados Unidos reclamarán todos los recursos del hemisferio occidental, incluyendo la propiedad intelectual y la historia en sí misma ${ }^{36}$.

\footnotetext{
33 Khristaan D. Villela, "Beyond Stephens and Catherwood: Ancient Mesoamerica as Public Entertainment in the Early Nineteenth Century", en Joanne Pillsbury, Past presented: archaeological illustration and the ancient Americas, 143.

34 Robert Aguirre, Informal Empire: Mexico and Central America in Victorian Culture (Minneapolis: University of Minnesota Press, 2005).

35 Para un análisis de la postura norteamericana ante la investigación arqueológica en tierras mesoamericanas ver Evans, Romancing the Maya: Mexican Antiquity in the American Imagination, 1820-1915

${ }^{36}$ Villela, "Beyond Stephens and Catherwood: Ancient Mesoamerica as Public Entertainment in the Early Nineteenth Century", 157.
} 


\section{El viaje de Catherwood y Stephens a Mesoamérica}

John Lloyd Stephens (Nueva Jersey, 1805-Nueva York, 1852), fue abogado de profesión, y viajero por convicción. Había realizado entre 1835 y 1836 un viaje que iniciaría en Italia, y lo llevaría a visitar parte de Europa, Egipto y el cercano Oriente. El relato de estos viajes fue editado bajo el nombre de Incidents of Travel in Egipto, Arabia Petrea and Tierra Santa, e Incidents of Travel in Grecia, Turquia, Rusia and Polonia, publicados por la editorial Harper \& Brothers, de su amigo James Harper, en 1837 y 1838 respectivamente $^{37}$. Al finalizar la travesía, Stephens había arribado a Londres, donde asistiría a un Panorama de Jerusalén, realizado a partir de los dibujos que el mismo Frederick Catherwood había realizado años antes. Los panoramas eran una atracción de moda en aquellos años, inventados por el irlandés Robert Barker en 1788, y consistían en el despliegue de imágenes panorámicas dentro de un recinto construido especialmente para este fin, que permitía al público presenciar escenas de sitios lejanos y exóticos a los cuales no muchos podían viajar, y que se renovaban periódicamente. John Stephens resultó gratamente impresionado por el trabajo de Catherwood, y luego de su encuentro en Londres logró convencerlo de trasladarse a Nueva York en 1836. Allí Catherwood instaló un estudio de arquitectura cerca de Wall Street y luego construyó su propio panorama, al cual denominó The Broadway Panorama ${ }^{38}$. También conocido como Catherwood Panorama, o Catherwood Rotunda, fue un edificio circular diseñado especialmente para exhibir pinturas panorámicas y, posteriormente, algunas de las antigüedades adquiridas en el nuevo continente. Este acercamiento de Catherwood a las imágenes a partir de la planificación de la construcción de panoramas, los cuales en muchos casos tomaba como temática temas arqueológicos, muy probablemente haya influido en el modo en que posteriormente abordaría la creación de imágenes en América. Los trabajos de Catherwood fueron concebidos para circular no en el circuito de las bellas artes, sino en circuitos más populares, como lo fueron los panoramas, la ilustración de relatos de viaje y la difusión de álbumes de grabados. Los artistas que crearon este tipo de imágenes durante el siglo XIX buscaban más

\footnotetext{
37 Víctor Von Hagen, Explorador maya. John Lloyd Stephens y las ciudades perdidas de América central y Yucatán (Buenos Aires: Librería Hachette, 1957), 81-82.

38 Bernard Comment, The Panorama (Chicago: University of Chicago Press, 2004), 56. El Brodway Panorama funcionó entre 1838 y 1842. Las panorámicas exhibidas fueron creadas a partir de los dibujos realizados por Catherwood en sus viajes por Europa, Egipto y el Cercano Oriente, y producidas por William Bullock. La primera exhibición del edificio fueron las Vistas de Jerusalén, seguidas por las vistas de las cataratas del Niágara, Lima, y Tebas Desafortunadamente en julio de 1842 un incendio destruyó el edificio, llevando la mayor parte del material realizado por Catherwood entre dibujos, daguerrotipos y grabados.
} 
un efecto de teatralidad e impacto en el espectador que la verosimilitud en la representación tal como la entendemos hoy en día ${ }^{39}$.

Fue especialmente provechoso en este sentido que John Stephens hubiese estado alimentando su interés por las tierras centroamericanas y las ruinas allí descubiertas, a partir de la lectura de los relatos de viajes de Antonio Del Rio, Guillermo Dupaix, Jean-Frédéric Waldeck y Juan Galindo ${ }^{40}$. Alentado por James Harper, quien consideraba que los relatos sobre esas tierras resultarían en un nuevo éxito editorial, finalmente se decidió en 1839 a aventurarse hacia aquella región y contratar a Catherwood como dibujante de la expedición, comprometiéndose a solventar todos los gastos del viaje, y a pagar por adelantado la suma de 1500 dólares por los derechos de publicación del material gráfico producido durante el viaje. La idea de producir imágenes que luego pudiese utilizar en su panorama seguramente haya terminado de definir su participación.

Las noticias sobre la región mesoamericana para aquel entonces eran, como hemos visto, escasas y fragmentarias, realizadas con diversos fines, y cuyos informes eran de dudosa rigurosidad. Los datos de las expediciones hablaban de las ruinas de imponentes ciudades, pero eran contrapuestas con las percepciones de los habitantes originarios de América, quienes para occidente no eran más que salvajes sin técnicas ni capacidades, y por tanto incapaces de haber construido aquellas maravillas antiguas. Los relatos del siglo XVI que describían la gran civilización azteca en tiempos de Cortés eran tomados por falsos, e incluso aquellos que consideraban estos relatos como verdaderos sostenían que los americanos eran incivilizados y sangrientos. Tanto los conquistadores como los misioneros habían prestado poca atención a los nombres que los indígenas daban a aquellas ciudades dispersas en el territorio yucateco. Incluso el dibujante Luciano Castañeda, el dibujante de la expedición comandada por Dupaix, insistía en que los indígenas americanos eran incapaces de reconocer las imágenes presentes en las ruinas ya que no las habían visto nunca.

Stephens se había informado de las teorías que circulaban en Europa, que sostenían que los pueblos antiguos que habían poblado América y construido esas ciudades eran en realidad descendientes de fenicios, vikingos, egipcios o incluso chinos, entre otros. La teoría quizá más aceptada era que descendían

\footnotetext{
39 Villela, "Beyond Stephens and Catherwood: Ancient Mesoamerica as Public Entertainment in the Early Nineteenth Century", 144.

40 Ver Brunhouse, En busca de los Mayas: Los primeros arqueólogos.
} 
de las tribus perdidas de Israel, postura que Jean Fréderick Waldeck sostenía, afirmando que los caldeos habían fundado la ciudad de Palenque y el resto de las ciudades que había recorrido dentro de la península de Yucatán habían sido construidas por hindúes. Stephens y Catherwood eran particularmente escépticos de las ilustraciones de Waldeck, en las cuales las ruinas americanas poseían símbolos egipcios y cuneiformes, o mascarones con trompas de elefantes.

John Stephens había comenzado a elaborar sus propias ideas y estaba ávido por confirmarlas a partir de su viaje, para lo cual realizó los preparativos necesarios, solventando los gastos en gran parte gracias a las ganancias que le habían proporcionado sus anteriores libros. Stephens logró también el apoyo del gobierno norteamericano, el cual había aprobado su solicitud para viajar a Centroamérica como Secretario de Asuntos Americanos ante la Confederación Centroamericana. Este nombramiento, según Evans, se encuadra en los esfuerzos por parte de los Estados Unidos por apropiarse simbólicamente del pasado mesoamericano y así postular su línea de ascendencia hasta un pasado glorioso, a la par de lo que la antigüedad griega y romana significaba para los europeos.

Fue en estas condiciones que Catherwood y Stephens desembarcaron en 1839 en las costas de Belice. Recorrieron a partir de allí distintos sitios entre los que se encontraban las ruinas de Copán, Quiriguá, Palenque y Uxmal, donde el viaje fue interrumpido por el delicado estado de salud de Catherwood. De regreso a Nueva York las experiencias de este primer viaje serían volcadas en dos volúmenes acompañados de setenta y ocho grabados en base a los apuntes tomados por Catherwood durante la travesía. En 1841 vería la luz la primera edición de Incidents of Travel in Central América, Chiapas and Yucatán, y sería el año en que ambos viajeros regresarían a la península yucateca para emprender un nuevo viaje de exploración en esa zona. Este segundo viaje tendría como fruto otros dos volúmenes titulados Incidents of Travel in Yucatán, publicados por primera vez en 1843 , e ilustrados por ciento veinte grabados creados en base a los dibujos y daguerrotipos realizados por Catherwood.

Como era esperado por ambos, las publicaciones fueron un éxito editorial y circularon rápidamente por los Estados Unidos y luego por Europa, consolidando los nombres de Stephens y Catherwood para la posteridad. Evidencia de este éxito es el hecho de que durante los seis meses posteriores a su primera publicación, se debieron realizar un total de once reimpresiones de los dos libros, con un total de aproximadamente 20000 ejemplares vendidos 
tan sólo en este periodo ${ }^{41}$. Incluso parte de los textos fueron traducidos al español en 1845 por Justo Sierra O’Reilly, y circularon por Yucatán tempranamente. Fue en 1844 cuando Frederick Catherwood publicaría en Londres una selección de las imágenes producidas durante ambos viajes, acompañadas de comentarios escritos por él mismo, que se editó bajo el nombre de Views of Ancient Monuments in Central América, Chiapas and Yucatán.

\section{Las vistas de antiguos monumentos en América Central, Chiapas y Yucatán}

Catherwood seleccionó veintiséis de las imágenes realizadas durante sus dos travesías junto a Stephens para luego colorearlas y escribir un comentario en cada una de ellas, junto a una breve introducción. Este volumen constituye por lo tanto el único texto de íntegra autoría del dibujante inglés, que si bien no tuvo una cantidad de ejemplares muy numerosa (sólo se imprimieron 300 ejemplares, ya que fue pensado como una edición exclusiva, coloreada a mano por el propio artista) es un documento invaluable para conocer el testimonio escrito de Frederick y comprender las relaciones entre su pensamiento y el expresado por Stephens en los libros de 1841 y 1843. En su portada, diseñada por Owen Jones, se presenta a Catherwood como autor, y en la primera página del mismo se lee la dedicatoria, a su amigo y compañero de aventuras John Stephens. Las láminas fueron realizadas por seis grabadores a partir de los dibujos originales de Catherwood ${ }^{42}$.

Si bien esta publicación no es un relato de viajes tradicional dada su extensión, su formato, y el hecho de que el valor está puesto en las imágenes más que en el texto, muchos de los elementos que presenta se relacionan estrechamente con los escritos de Stephens. Es una constante en ambos, por ejemplo, el afán por demostrar exactitud en la descripción de los detalles, las medidas de los objetos y por reforzar esta fidelidad describiendo las circunstancias adversas que tuvieron que superar para lograr las imágenes y descripciones presentadas: "En términos estructurales, abrir un relato de viaje con la narración de una serie de peligros a los que el viajero se enfrenta y que

\footnotetext{
41 Evans, Romancing the Maya: Mexican Antiquity in the American Imagination, 1820-1915, 70.

${ }^{42}$ Para las atribuciones de cada lámina vease Frederick Catherwood, Views of Ancient Monuments in Central America, Chiapas and Yucatan (Londres, 1844).
} 
ponen en riesgo su vida refuerza, sin duda, la atención de sus lectores; es un recurso conocido y útil para asegurar la alta expectativa de la recepción" ${ }^{43}$. También se menciona la mediación de la cámara lúcida, la cual permitió a Catherwood un acercamiento a las estructuras a través de un instrumento que respaldaría de algún modo la objetividad de sus imágenes. Recordemos que utilización de elementos de observación fue característica de una época en la cual la visualidad pasaba a ser el centro de percepción y así de la adquisición de conocimiento. Incluso esta importancia es remarcada por el hecho de que, entre el primer y el segundo viaje realizado por Stephens y Catherwood a Centroamérica, este último adquirió un daguerrotipo -inventado apenas cuatro años antes- para respaldar el proceso de toma de imágenes. Sin embargo, dados algunos inconvenientes técnicos, Catherwood no realizó ninguna fotografía propiamente dicha en la travesía ${ }^{44}$. A cambio de eso, Catherwood optó por tomar bocetos in situ durante el viaje, ayudándose en muchos casos con la cámara lúcida. Luego los bocetos eran utilizados para generar las distintas composiciones, lo cual es especialmente evidente en las láminas que componen el portfolio de 1844. En ellas se puede apreciar el modo en el cual interactúan las ruinas con elementos del paisaje que incluye la vegetación, algunos animales, y elementos incluso del clima para lograr el efecto deseado en sus imágenes.

Debemos tener presente que toda ilustración inviste una autoridad que muchas veces trasciende incluso a su objeto de representación: a través de recursos como la simplificación de ciertos aspectos, la amplificación de otros, y de mediar el foco de atención que ponemos en el objeto representado, la imagen constituye en sí misma un objeto de estudio. Dentro de la tradición arqueológica la ilustración ha sido mucho más influyente frecuentemente que los mismos textos, dada su forma de presentar de un modo más inmediato el objeto de estudio, y de salvar muchas veces la distancia con el observador. Esta es la principal causa del papel preponderante que han cumplido en la producción de conocimiento. Reconocer las imágenes como fuentes de información requiere analizar el modo en que la información es organizada, codificada, percibida e intercambiada ${ }^{45}$.

\footnotetext{
${ }^{43}$ Depetris, "El relato de viaje moderno: ¿posmodernidad escondida?”, 123.

44 Existió en forma contemporánea al viaje de Stephens y Catherwood un expedicionario, Emanuel von Friedrichstal, quien tomó algunos daguerrotipos en Yucatán, pero estos nunca trascendieron de forma masiva, como sí lo hizo el trabajo de Stephens y Catherwood. Para ampliar el tema ver Arturo Taracena Arriola y Adam T. Sellen "Emanuel von Friedrichsthal : su encuentro con Mesoamérica y su descripción de Chichén Itzá”, en Carolina Depetris (ed.), Viajeros por el mundo maya, (Mérida: UNAM, 2010).

45 Pillsbury, Past presented: archaeological illustration and the ancient Americas, 3.
} 


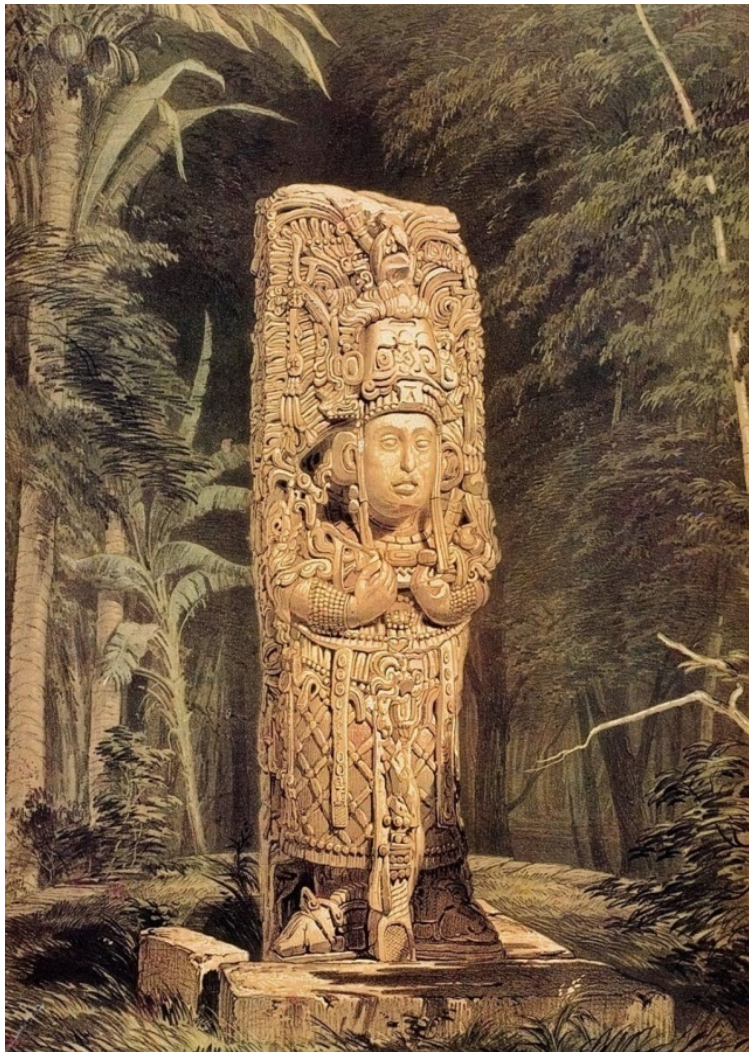

Figura 1. Catherwood, Frederick. Plate I. Idol, at Copán. Views of Ancient Monuments in Central America, Chiapas and Yucatan. Londres: F. Catherwood, 1844.

Durante la travesía de Stephens y Catherwood la mirada se convertía en partícipe del acto de descubrimiento de las ruinas, de la apreciación de su monumentalidad, de la contemplación del paisaje que se abría a su vista o de la selva que se cerraba sobre ellos. En este contexto la plasmación de las sensaciones y percepciones vividas era una forma de "poner orden en el caos de sensaciones y en el fárrago perceptivo en que se ven inmersos, acentuando la distancia con respecto a la experiencia e instituyendo la figura del autor" ${ }^{\prime 46}$.

El texto, tanto visual como escrito muestra entonces un afán descriptivo y documental, pero a su vez tiene una fuerte carga narrativa, tanto en las escenas que decide mostrar como en la organización misma de las láminas. Catherwood ordena el discurso visual abriendo su serie con una imagen de una

46 Penhos, Ver, conocer, dominar. Imágenes de Sudamérica a fines del siglo XVIII, 221. 
estela de Copan (fig. 1), que alude por un lado cronológicamente al inicio de la travesía, pero por otro lado es una imagen que se auto-presenta: un antiguo gobernante recibe al lector con una presencia imponente, majestuosa, inmerso en la espesa selva, lo que nos lleva a preguntarnos por su identidad y la de sus creadores. Se observa la centralidad del objeto principal de la representación, que destaca con sus tonos cálidos, modelados por la iluminación, frente al verde oscuro del contexto. Los elementos de la vegetación son tratados como un marco literal de la imagen y como un contexto que intenta evidenciar la ubicación de la ruina. A la majestuosidad de la imagen se contrapone por momentos la exactitud racional del relato, en el que Catherwood narra las dificultades atravesadas para poder lograr la realización del dibujo, y da detalles precisos sobre las características y medidas de la escultura:

The Plate gives a front view of one of the most perfect of a group of eleven. They were all deeply buried amidst tropical trees when first discovered, and it was with no small difficulty that a sufficient space was cleared away to admit of a drawing being made. The Idol is carved out of a single block of compact limestone, and measures eleven feet eight inches in height, and three feet four inches each side, standing on a pedestal six feet squaret. [La Lámina muestra una vista frontal de uno de los más perfectos ejemplares de un grupo de once. Todos elllos estaban sumergidos profundamente entre los árboles tropicales cuando fueron descubiertos por primera vez, y pudo ser despejado, no sin dificultad, un espacio suficiente para permitir la realización del dibujo. El ídolo está tallado en un solo bloque de piedra caliza compacta, y mide once pies con ocho pulgadas de altura, y tres pies cuatro pulgadas de cada lado, parado sobre un pedestal de seis pies de lado $]^{48}$.

Esta información nos pone en el contexto de una percepción situada, en la cual el cuerpo media el conocimiento, y a la vez realza el valor y la veracidad de la imagen. La misma es elevada a la categoría de prueba, e incluso con una carga expresiva transmitida de forma más inmediata que la descripta a través las palabras: "el discurso escrito representa en términos evocativos experiencias de orden visual, pero por su propia lógica y funcionamiento, no las provoca, en tanto que las imágenes son representaciones de datos de la realidad visual que además se presentan como nuevas experiencias visuales”49.

\footnotetext{
${ }^{47}$ Frederick Catherwood, Views of Ancient Monuments in Central America, Chiapas and Yucatan, (London: F. Catherwood, 1844): 11, https://archive.org/details/gri_33125012602591.

48 Todas las traducciones del texto de Catherwood son de mi autoría.

49 Penhos, Ver, conocer, dominar. Imágenes de Sudamérica a fines del siglo XVIII, 23.
} 
Las láminas siguientes poseen características compartidas con esta primera, mostrando una construcción de la imagen sumamente teatral, en la cual la narración está marcada por la atmosfera de las imágenes, la iluminación cenital, el carácter de aparición que logra Catherwood al limpiar el sitio alrededor del objeto a retratar y a la vez colocar la vegetación como un marco que cubre el resto de la superficie, en la cual prácticamente no puede verse el cielo. A través de estas construcciones, atravesadas por rasgos románticos, que nos recuerdan su formación junto al maestro Fuseli, Catherwood nos muestra no sólo los monumentos, sino también nos habla de su percepción de una vegetación y clima que son el escenario de estas ruinas, y su sensación de inmersión en esta naturaleza que todo lo cubre y envuelve.

En la lámina IV (fig.2) se muestra la estela $\mathrm{C}$ de Copan tal como fue encontrada en la expedición, quebrada y con una parte yaciendo en el suelo. Se observa claramente el modo en que se recorta el espacio en el cual se encuentra la escultura, la cual parece estar en parte sumergida en el suelo empantanado de la selva. La vegetación ofrece un marco espacial que ayuda a centrar la atención en el monumento, a la vez que se muestra amenazante. Este efecto es reforzado por la iluminación, tanto la que se despliega sobre la escultura como la que aparece de manera intensa por detrás de la escena, en medio de las nubes tormentosas. Esta imagen fue redibujada de su boceto original, colocando el espejo de agua, el venado y el rayo detrás, todos añadidos posteriormente para resaltar dramáticamente la imagen de las ruinas. Aquellas introducciones resultan sustanciales para la construcción de sentido que se proponía Catherwood en sus imágenes ${ }^{50}$. Recordemos, no sólo buscaba general un registro fidedigno de las ruinas en el marco de las representaciones científicas. También quería crear un gran efecto visual para el cada vez más extenso público que acudía a los panoramas, y que adquiría libros de viajes y álbumes de grabados de antigüedades.

\footnotetext{
${ }^{50}$ Pillsbury, Past presented: archaeological illustration and the ancient Americas, 18.
} 


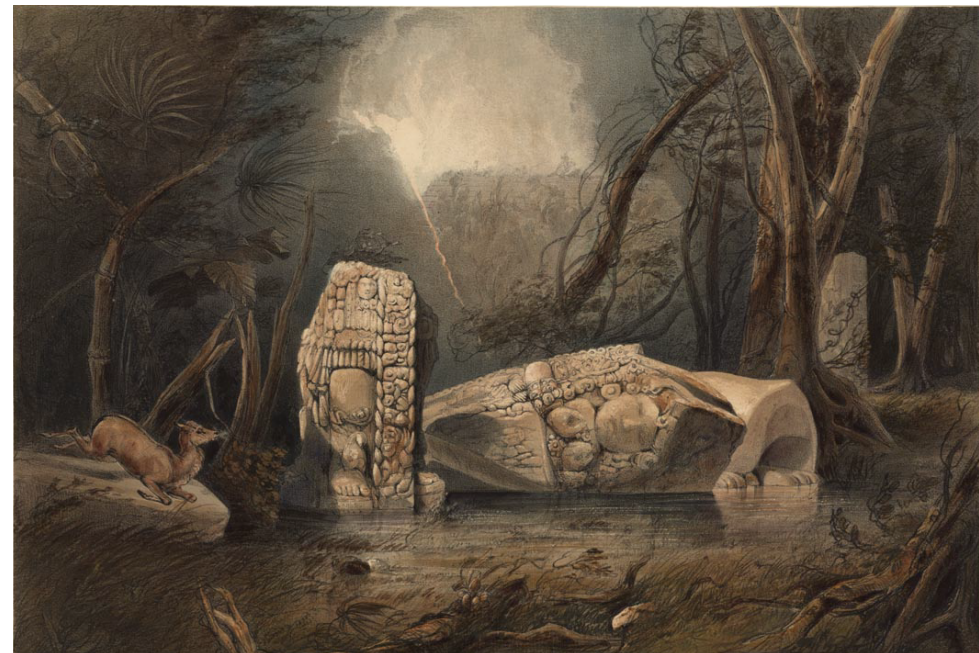

Figura 2. Catherwood, Frederick. Plate IV. Broken Idol, at Copán. Views of Ancient Monuments in Central America, Chiapas and Yucatan. Londres: F. Catherwood, 1844.

La atmósfera de esta imagen recuerda algunas de las escenas inquietantes del maestro de Catherwood, Henry Fuseli, como parte de la tradición romántica a la cual el maestro perteneció, en la que se resaltaba a la naturaleza como portadora de fuerzas indómitas. Catherwood deja en claro su interés por el tema retratado y refuerza el carácter narrativo de esta imagen, que trasciende su función descriptiva:

This Idol, in his ruined state, is one of the most beautiful in Copán, and in workmanship, is equal to the best remains of Egyptian art. Its present condition may give some idea of the scene of desolation and ruin presented at Copan. The whole region is an overgrown forest, and, amidst the prostration and wreck of buildings and terraces, one "Idol" is seen displaced from its pedestal by monstrous roots, another locked in the close embrace of branches of trees, and almost lifted out of the earth, and another hurled to the ground, and bound down by large vines and creepers: of this, the fallen part was thus completely bound to the earth, and, before it could be drawn, it was necessary to unlace them, and tear the fibres out of the crevices. The fallen statue is of about the same dimensions with the others. The paint is very perfect, and has preserved the stone, which makes it more to be regretted that it is broken. The altar is buried, with the top barely visible, which, by excavating, we made out to represent the back of a tortoise ${ }^{51}$. 
[Este Ídolo, en su estado de ruina, es uno de los más bellos de Copán, y en cuanto a su artesanía, es igual a los mejores ejemplares del arte egipcio. Su condición actual puede dar alguna idea de la escena de desolación y ruina presentada en Copán. Toda la región es un bosque cubierto de vegetación, y, en medio de la postración y la ruina de edificios y terrazas, se ve un ídolo desplazado de su pedestal por raíces monstruosas, otro encerrado en el estrecho abrazo de ramas de árboles y casi levantado de la tierra, y otra arrojado al suelo, y atado por grandes lianas y enredaderas; por esto, la parte caída estaba completamente agarrada a la tierra y, antes de que pudiera ser extraída, fue necesario desatarla, y arrancar las fibras fuera de las grietas. La estatua caída es aproximadamente de las mismas dimensiones que las otras. La pintura está en perfectas condiciones, y ha conservado la piedra, lo que hace más lamentable que se haya roto. El altar está enterrado, con la parte superior apenas visible, que, al excavar, comprendimos que representaba la parte posterior de una tortuga.]

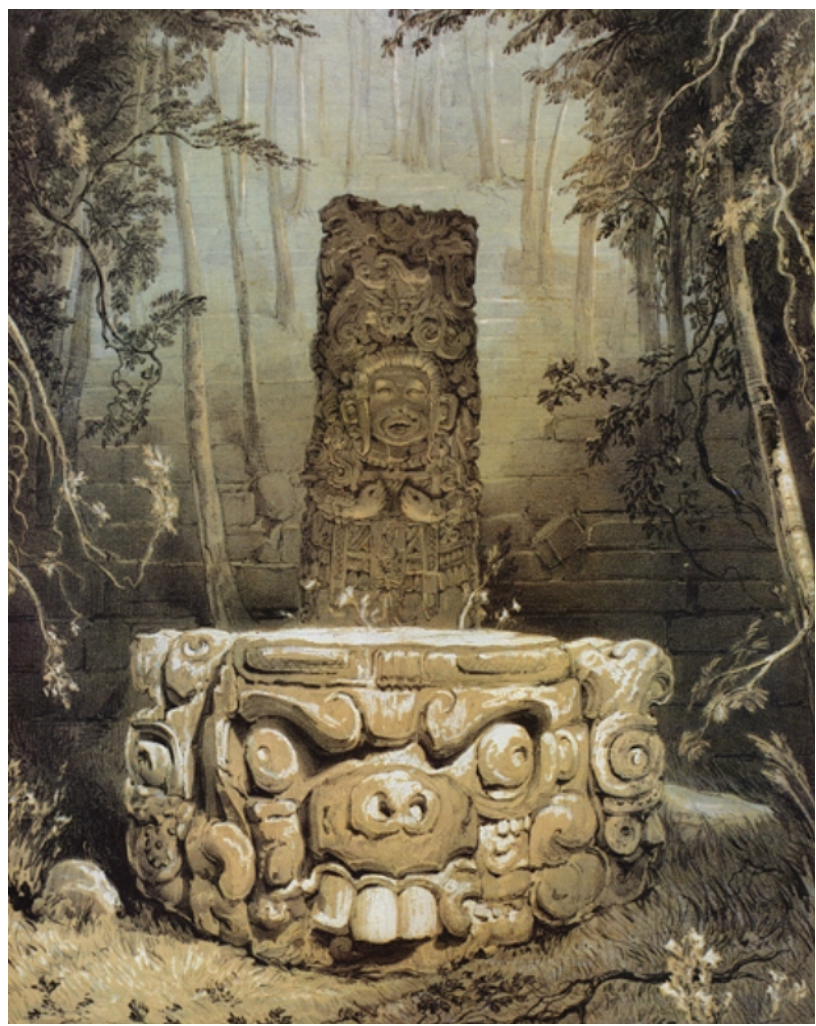

Figura 3. Catherwood, Frederick. Plate V. Idol and altar, at Copán. Views of Ancient Monuments in Central America, Chiapas and Yucatan. Londres: F. Catherwood, 1844. 
Aquí puede verse también cómo Catherwood no duda en equiparar el valor artístico de los monumentos americanos con las admiradas obras del arte egipcio, de las cuales puede hablar de manera bien informada, ya que tuvo la oportunidad de observarlas y dibujarlas en detalle en los años que pasó en Egipto junto a Robert Hay. No sólo se observa el valor dado a las producciones artísticas americanas, sino que también es puesto en evidencia el conocimiento y respeto por los relatos de los conquistadores respecto de las costumbres de los pueblos americanos a su llegada, trazando de esta forma relaciones entre aquellos relatos y las ruinas por las cuales está transitando:

In this Plate, the altar, or sacrificial stone, forms the principal object in the fore-ground. It is three feet six inches high, above the ground, and measures seven feet from angle to angle. It is sculptured into four hideous heads of colossal size, having enormous fangs, and distended eyes, adding, no doubt, the finishing horror to the bloody sacrifices which there can be little doubt were enacted on it. Certain channels (now nearly obliterated) exist on its upper surface, to carry off the blood of the human victim, and to render the operation of cutting open the breast, and tearing out the heart more easy, the upper surface of the stone is slightly convex, agreeing with the accounts of the early Spanish discoverers ${ }^{52}$.

[En esta Lámina, el altar, o piedra de sacrificios, conforma el objeto principal hacia el frente. Tiene tres pies y seis pulgadas de alto, por encima del suelo, y mide siete pies de ángulo a ángulo. Está esculpida con cuatro horribles cabezas de tamaño colosal, con enormes colmillos y ojos distendidos, que añaden, sin duda, el horror final a los sacrificios sangrientos que con poco lugar a dudas, fueron realizados en ella. Existen en la parte superior de su superficie ciertos canales (actualmente casi borrados), para drenar la sangre de la víctima humana, y para hacer la operación de cortar el pecho, y desgarrar el corazón más fácilmente, la superficie superior de la piedra es ligeramente convexa, lo cual concuerda con los relatos de los primeros descubridores españoles.]

La imagen a la cual alude el fragmento (fig. 3) efectivamente pareciera escenificar una posible acción ritual, cargada de dramatismo, y enmarcada por la composición piramidal que atrae la mirada del espectador desde el vértice superior formado por las hileras de arboles, a través de la estela central con la representación de "some deified hero or chieftain, from certain traces of individuality

\footnotetext{
52 Catherwood, Viems of Ancient Monuments in Central America, Chiapas and Yucatan, 12.
} 
in the features" ${ }^{\prime 53}$ [algún héroe deificado o jefe, a juzgar por ciertos rasgos de individualidad en su rostro], hasta llegar a la imponente figura del altar sacrificial descrito por Catherwood.

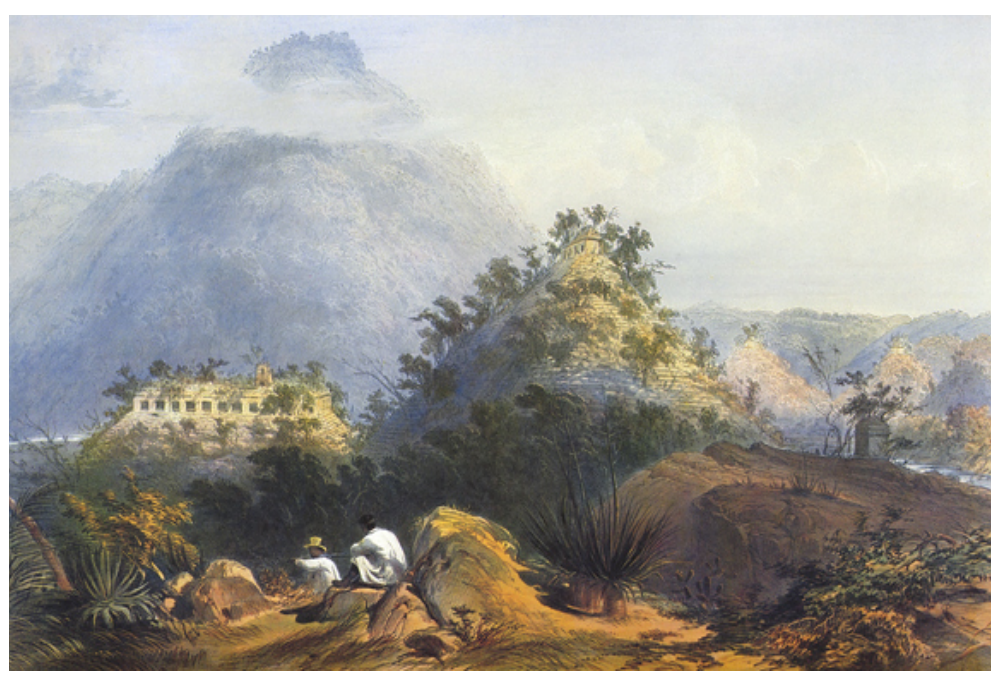

Figura 4. Catherwood, Frederick. Plate VI. General View of Palenque. Views of Ancient Monuments in Central America, Chiapas and Yucatan. Londres: F. Catherwood, 1844.

A partir de la lámina número IV (fig. 4) la vista se abre al paisaje y la escena se organiza en planos sucesivos, en donde el dibujante se ubica dentro del encuadre, habilitando la mirada del espectador desde su mismo punto de vista, y donde toman cada vez más presencia los indígenas del lugar. Luego ubica las ruinas a explorar, y funde estas escenas en la distancia, hacia cielos brumosos, donde por momentos algunos elementos del paisaje habilitan quizás a imaginar nuevos vestigios ocultos por la vegetación. Aquí el escenario cambia, pero también cambia de a poco el sentido de la narración. La claridad con la cual se muestran los elementos deja aparte al misterio y todo se presenta de manera más inmediata al espectador, limitando las escenas misteriosas para algunas representaciones de los interiores de las estructuras exploradas, que intercala con estas vistas.

En la vista de Palenque (fig. 4), Catherwood muestra una composición organizada a parir de varios de los edificios explorados en el lugar:

${ }^{53}$ Catherwood, Views of Ancient Monuments in Central America, Chiapas and Yucatan, 12. 
It is due to the reader to state, that this general view of Palenque is composed of separated sketches of each Casa, or Building, and from the ground-plan each is made to occupy its respective position. No other method could be adopted, as the large size of the trees, and dense nature of the forest, precluded any idea of making a clearing sufficient to embrace them all in one view. The clearing is, therefore, not real, but imaginary. The reminder of the drawing may be considered as quite faithfupt.

[Se debe aclarar al lector que esta visión general de Palenque está compuesta por bocetos separados de cada Casa o Edificio y desde el plano que de cada uno se hizo para ocupar su respectiva posición. Ningún otro método podía ser adoptado, ya que el gran tamaño de los árboles, y la naturaleza densa del bosque, excluían la idea de hacer un claro suficiente para abarcarlos todos en una misma visión. El claro no es, pues, real, sino imaginario. El recuerdo presentado en del dibujo puede ser considerado como muy fiel.]

Aquí Catherwood muestra otra faceta de su proceder como dibujante, un nuevo método empleado a fines ya no de mostrar una escena con un tinte de descubrimiento sino con el afán de clarificar la disposición de aquel sitio. Esto demuestra un conocimiento más profundo de cada uno de los edificios y una búsqueda concreta de mostrarlos de manera inmediata, de exponer la planificación de la ubicación de aquellas estructuras según un plan racional.

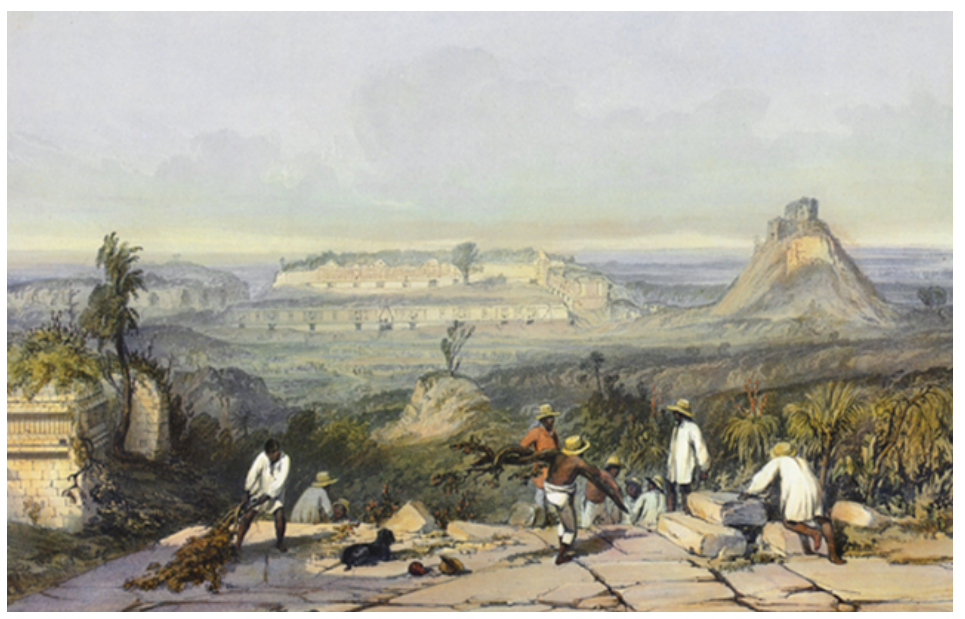

Figura 5. Catherwood, Frederick. Plate VIII. General View of Las Monjas, at Uxmal. Views of Ancient Monuments in Central America, Chiapas and Yucatan. Londres: F. Catherwood, 1844. 
En la vista de Las Monjas, Uxmal (fig. 5), la organización de la composición es muy similar, pero esta vez el artista no habla de una composición fragmentaria -si bien se observa la ubicación de los elementos y dimensiones adaptadas a los requerimientos de la plasmación en un soporte único- ya que la naturaleza del norte de Yucatán, distinta del carácter selvático de Chiapas, posiblemente haya permitido visualizar de manera más inmediata la ubicación de las estructuras. Aquí Catherwood se limita a exponer las dimensiones y ubicación de los edificios, haciendo referencias a los otros grabados en los cuales puede observarse en detalle cada uno de ellos.

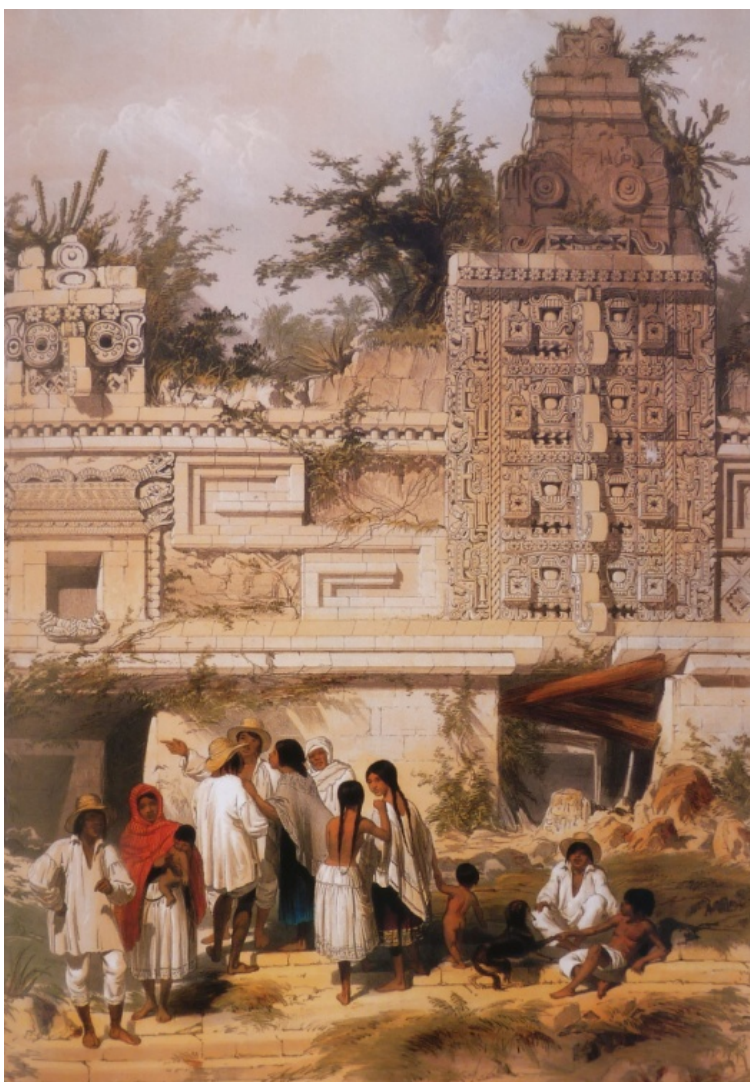

Figura 6. Catherwood, Frederick. Plate XV. Portion of la Casa de las Monjas, Uxmal. Views of Ancient Monuments in Central America, Chiapas and Yucatan. Londres: F. Catherwood, 1844. 
Desde aquí y hasta el final de la narración se observa cada vez de manera más frecuente la presencia de lugareños desarrollando escenas variadas: incluso se observan a los niños y mujeres en actividades cotidianas (fig.6). Si bien los comentarios que acompañan estas imágenes se limitan a hablar de los edificios, es sumamente llamativa la atención prestada en la representación de las actitudes de los indígenas y en la inclusión cada vez mayor de personas que interactúan entre ellas y que muestran sus costumbres. Desde el inicio Catherwood deja entrever a lo largo de sus comentarios la atención puesta a los nombres dados por los locales a los sitios e incluso a las estructuras individuales que fueron encontrando durante el viaje, lo cual demuestra en algún punto el interés de los viajeros respecto de lo que los nativos americanos conocían respecto de aquellas ruinas. Uno de los comentarios de Catherwood inicia hablando puntualmente de las actividades de los indígenas:

The Rancho of Sabacché lie son the Camino Real from Ticul to Bolonchen. It is inhabited entirely by Indians, and it is distinguished by a well, build by the present proprietor of the Rancho. Formerly the inbabitants were dependent entirely upon the well at Tabi, six miles distant. Besides its real value, this well presented a curious and lively spectacle. A group of women was around. It had no rope or fixtures of any kind for raising water, but across the mouth was a round beam, laid upon two posts, over which the women were letting down and hoisting up little bark buckets. Every woman brought with her, and carried away, her own bucket and rope, the latter coiled up and laid on the op of her head, with the end hanging down behind, and forming a sort or head-dress ${ }^{55}$.

[El Rancho de Sabacché se encuentra el Camino Real que va de Ticul a Bolonchen. Está habitada enteramente por indios, y se distingue por una fuente, construida por el actual propietario del Rancho. Anteriormente los habitantes dependían enteramente de la fuente de Tabi, a seis millas de distancia. Además de su valor real, esta fuente presentaba un espectáculo curioso y animado. Había un grupo de mujeres. No tenían cuerdas ni accesorios de ningún tipo para extraer el agua, pero a través de la boca había una viga redonda, colocada sobre dos postes, sobre la cual las mujeres dejaban caer y alzaban pequeños cubos de corteza. Cada mujer traía consigo y llevaba su propio cubo y cuerda, la cual s enroscaba y posaba sobre su cabeza, con el extremo colgando detrás, y formando así una especie de tocado.]

\footnotetext{
${ }^{55}$ Catherwood, Views of Ancient Monuments in Central America, Chiapas and Yucatan, 20.
} 
Teniendo en cuenta que el compilado consta de tan sólo de veintiséis grabados, y que este fragmento ocupa prácticamente la mitad del comentario destinado a la Lámina XVIII, podemos darnos una idea de la importancia que Catherwood otorgó a los indígenas americanos. Y si sumamos esto a las declaraciones hechas por Stephens en los Incidents of Travel..., teniendo en cuenta la sintonía en el pensamiento de ambos viajeros, es posible arriesgar una interpretación sobre la inclusión de los indígenas en los grabados. Esta presencia puede ser leída como un contundente manifiesto, presente también en los escritos de Stephens: esos pobladores que Catherwood retrata son los descendientes de las culturas que construyeron ese majestuoso escenario en el cual el dibujante los ubica. Por primera vez se asume que esta cultura americana es una civilización en sí misma, original y distinta de las demás. Aquí la narración de escenas en las imágenes se entrelaza con la narración histórica que produce un salto en el tiempo para relacionar a los habitantes de Yucatán con los grandes constructores y artistas del pasado, y responde de alguna forma a las intrigas que nos había presentado aquel gobernante de la estela de Copán, al inicio del libro.

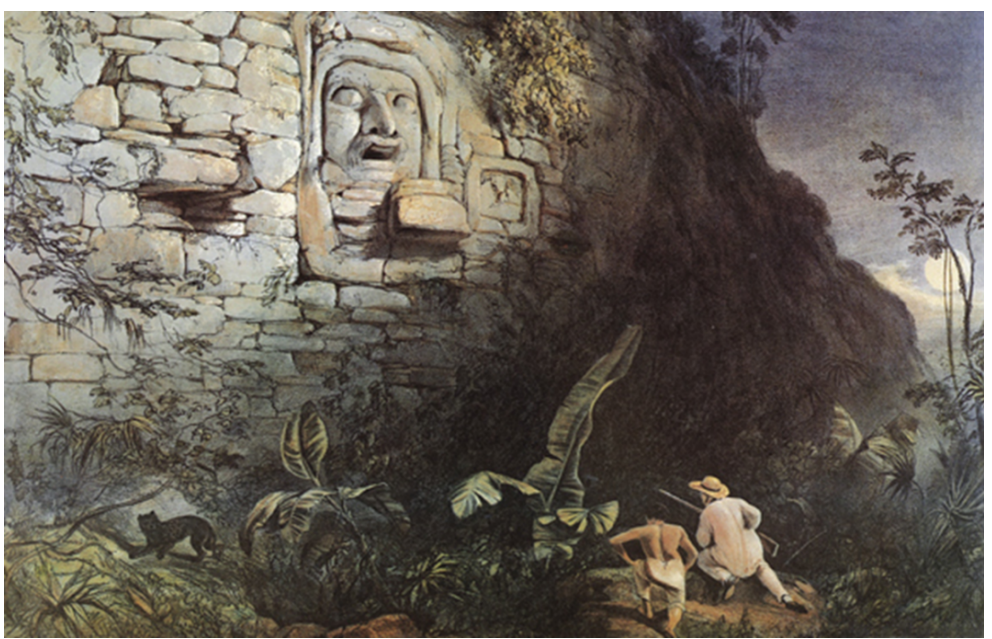

Figura 7. Catherwood, Frederick. Plate XXV. Colossal Head, at Izamal. Views of Ancient Monuments in Central America, Chiapas and Yucatan. Londres: F. Catherwood, 1844.

La última imagen del compendio (fig. 7) parece estar colocada allí como un cierre pintoresco a esa aventura: es la única escena que se muestra de noche y en ella se ve un paisaje en parte imaginario, en el cual dos hombres intentan 
cazar un jaguar al pie de un acantilado, con un gran mascarón presidiendo la escena. La luna marca un camino de salida en medio del cielo más despejado que se puede observar en toda esta serie de grabados, mezclando una cierta nostalgia por abandonar aquellas tierras, pero probablemente con la tranquilidad de haber resuelto, según sus propias convicciones, el misterio sobre aquellas ruinas mesoamericanas.

\section{Conclusiones}

Las Views of Ancient Monuments in Central América, Cbiapas and Yucatán se constituyen en un testimonio único, en el cual podemos acceder de forma casi inmediata a las ideas de Frederick Catherwood, el gran dibujante ingles pionero en los estudios de la cultura Maya. Su importancia radica en que, junto a Stephens, abrieron la puerta a las futuras investigaciones sobre las antiguas culturas que habitaron Mesoamérica, aportando una mirada mucho más sistemática sobre el territorio, postulando relaciones entre los distintos sitios visitados, a la vez que diferencias con las culturas del viejo continente o de oriente, y generando además un importante registro documental. Prueba de ello es la mención de estos viajeros por parte de la mayoría de los grandes exponentes del estudio de la cultura maya, y el valor otorgado a los registros visuales generados por Catherwood, que han sido una herramienta inestimable para reponer datos de piezas luego perdidas: "The first Maya art to become widely known, for example, came from Palenque and Copan, largely by means of Catherwood's engravings. They emphatized human forms and placed particular emphasis on faces, especially when compared with the conventionalized human figures of the Aztec art" ${ }^{56}$. [El primer arte maya que se conoció ampliamente, por ejemplo, vino de Palenque y Copan, en gran parte a través de grabados de Catherwood. Estos enfatizaron las formas humanas y pusieron especial énfasis en las caras, especialmente cuando se las compara con las figuras humanas convencionalizadas del arte azteca].

Las imágenes de Catherwood colocan a la vista como medio privilegiado para la adquisición de conocimiento, depositando en ella la confianza como vía de acceso al mundo fenoménico, pero a la vez poseen una opacidad

\footnotetext{
56 Linda Schele y Mary Miller, The blood of Kings: dynasty and ritual in Maya art, (New York: George Braziller, 1992), 20. La traducción es de mi autoría.
} 
respecto de lo que representan, que habilita a identificar en ellas las tensiones entre la plasmación fiel de la realidad según las exigencias de cientificidad, y la intervención de la subjetividad del artista. Se entrelazan en ellas, de la misma forma que en los textos de los relatos de viajes, la precisión de la mirada científica y una narración personal marcada por el romanticismo, que invitan a seguir descubriendo aquel territorio. Podemos pensar a partir de ello en el poder de las imágenes como vehículo de ideas, actitudes, percepciones y valoraciones, proyectadas por un sujeto moderno, escindido del mundo pero que siempre mira desde un punto de vista, subjetivamente. La imagen es portadora de rasgos de emocionalidad, sensibilidad e intuición y funciona a la par de la exigencia de un conocimiento científico, ligado a lo racional. Las imágenes de Catherwood se insertan en la tradición de la representación anticuaria, que será de valor fundamental en el surgimiento de las nuevas ciencias, especialmente de la antropología. A su vez, a través de los recursos propios del romanticismo en el cual se formó, este artista crearía imágenes impactantes para su circulación ante un público masivo.

Hemos intentado a partir de este recorrido mostrar a Frederick Catherwood como un artista único, que logra conectar Europa, Norteamérica y Mesoamérica. Su formación en la Royal Academy of Arts de Londres con el maestro del romanticismo Henry Fuseli y su descubrimiento de las imágenes de Giovanni Battista Piranesi marcaron su estilo y sus intereses estéticos. Sus trabajos como dibujante de las arquitecturas londinenses y luego de arquitecturas y ruinas europeas, egipcias y de Medio Oriente funcionaron como preparación para su labor en Centroamérica. La experiencia europea del Grand Tour lo marcó como viajero ávido de nuevas tierras por descubrir y lo estableció como un dibujante de antigüedades, creador de imágenes de gran valor epistemológico a inicios del siglo XIX. Pero fue su llegada a los Estados Unidos y su relación con John Lloyd Stephens las que cimentaron la posibilidad de viajar hacia Centroamérica, y que posiblemente hayan influido en sus ideas a través de los intereses norteamericanos en la apropiación simbólica de un pasado glorioso que consideraron auténtico, e igual de valioso que el pasado griego y romano de los europeos. Esto consolidó la posibilidad de comparar la identidad de los edificios vistos por Catherwood en sus viajes previos y proponer a partir de esto la singularidad de aquellas construcciones y el valor absoluto de los americanos como constructores de esas maravillosas ciudades.

Las imágenes de Catherwood se inscriben dentro de una importante tradición de representación que entrelaza sus raíces con las de la arqueología 
americana, y el hecho de que se hayan transformado en fuentes documentales nos obliga a focalizar detenidamente en los recursos que pone en juego al construir sus obras. La creación de imágenes fue un campo de proyección de ideas y también un campo creciente de disputas acerca de las teorías de las ciencias. Es por ello que los aportes de Frederick Catherwood constituyen una mirada novedosa sobre el territorio mesoamericano: postulan la grandeza de la producción cultural de la antigüedad americana, y la reconocen como auténtica y original, no influida o copiada de una civilización europea u oriental. Esto se constituye como un punto de partida esencial para la construcción de conocimiento subsiguiente por parte de las investigaciones norteamericanas y europeas.

La fama obtenida por las publicaciones de Stephens y Catherwood permitirá la difusión de esta nueva visión en Europa, comenzando a sellar los debates generados desde el siglo anterior sobre el origen de los monumentos americanos. No tardarán las demás naciones europeas (francesa e inglesa especialmente) en trabajar dentro de este nuevo paradigma, en el estudio de estas antiguas civilizaciones americanas. Las imágenes de Catherwood generaron una necesidad creciente de exploraciones en busca especialmente de objetos con los cuales expandir los museos Británicos y con los cuales fundar los museos norteamericanos. Por eso consideramos importante interrogar a las imágenes de Catherwood: para entender cómo dieron forma a visiones e ideas, y en qué modo ciertas visiones e ideas modelaron la creación de estas imágenes. Con este aporte esperamos entonces contribuir al reconocimiento del gran legado de Frederick Catherwood al estudio de las antiguas culturas mesoamericanas.

\section{Bibliografía}

Aguirre, Robert D., Informal Empire: Mexico and Central America in Victorian Culture, Minneapolis: University of Minnesota Press, 2005.

Baudez, Claude y Sidney Picasso, Lost cities of the Maya, Londres: Thames \& Hudson, 1992.

Bourbon, Fabio. The lost cities of the Mayas: the Life, Art, and Discoveries of Frederick Catherwood. México: Artes de México, 1999. 
Brunhouse, Robert. En busca de los Mayas: los primeros arqueólogos. México: Fondo de Cultura Económica, 2013.

Catherwood, Frederick. Views of Ancient Monuments in Central America, Chiapas and Yucatan. Londres: F. Catherwood, 1844.

Colombi, Beatriz: "El Viaje y su Relato". Latinoamérica. Revista de Estudios Latinoamericanos, $\mathrm{n}^{\circ} 43$, (2006): 11-35.

Comment, Bernard. The Panorama. Chicago: University of Chicago Press, 2004.

Depetris, Carolina. El héroe involuntario. Fréderic de Waldeck y su viaje por Yucatán. México: Universidad Nacional Autónoma de México, Centro Peninsular en Humanidades y Ciencias Sociales, 2014.

. "El relato de viaje moderno: ¿posmodernidad escondida?". Cuadernos del CILHA 14, n 19 (2013): 109-126.

. "El orientalismo como episteme: Frédéric de Waldeck y las ruinas mayas", en HiN - Revista Internacional de Estudios Humboldtianos, XI: 21 (2010): 10-23.

. (ed.) Viajeros por el mundo maya, Universidad Nacional Autónoma de México, Mérida, 2010.

Duviols, Jean Paul. "Visión primitiva del Nuevo Mundo según los viajeros europeos". En 1492 Dos mundos, paralelismos y convergencias. XII Coloquio Internacional de Historia del Arte. México: UNAM, 1991.

Evans, R. Tripp. Romancing the Maya: Mexican Antiquity in the American Imagination, 1820-1915. Austin: Univesity of Texas Press, 2004.

Galindo, Juan, "Memoire de M. Juan Galindo officier superieur de la republique de l'Amerique centrale, sur les ruines de Palenque", en Bulletin de la Société de géographie de Paris, $\mathrm{n}^{\circ} 18$ (1832):198-214.

Kingsborough, Edward King, Antiquities of Mexico, 7 vols, Londres: R, Havell, J.Moyes \& R. Taylor,1831.

Landa, Diego de, Relación de las cosas de Yucatán. Estudio preliminar, cronología y revisión del texto María del Carmen León Cázares, México: Conaculta, 2003.

Morley, Sylvanus G., The Inscriptions At Copan, Washington DC: Carnegie Institute, 1920.

Penhos, Marta. "Viajes, viajeros e imágenes: una relación necesaria". En Travesías de la imagen. Historias del arte en la Argentina, editado por María Isabel 
Baldasarre y Silvia Dolinko. Vol. 2. Buenos Aires: Centro Argentino de Investigadores de Arte/ EDUNTREF, Archivos del CAIA IV, 2012.

- Ver, conocer, dominar. Imágenes de Sudamérica a fines del siglo XVIII. Buenos Aires: Siglo XXI Editores, 2005.

Pillsbury, Joanne (ed.), Past presented: archaeological illustration and the ancient Americas, Washington D.C: Dumbarton Oaks, Harvard Univ. Press, 2012.

Pratt, Mary Louise, Ojos imperiales. Literatura de viajes y transculturación, México: Fondo de Cultura Económica, 2010.

Ranking, John, "Remarks on the Ruins at Palenque, in Guatemala, and on the Origin of the American Indians", en Quarterly Journal of Science, Literature and Art, Londres (1828):135-154.

Rebok, Sandra. "La expedición americana de Alexander Von Humboldt y su contribución a la ciencia del siglo XIX". Bulletin de l'Institu Francais d'Etudes Andines 32, n³ (2003): 441-458.

Río, Antonio del, Description of the Ruins of an Ancient City, Discovered Near Palenque, in the Kingdom of Guatemala, in Spanish America: Translated from the Original Manuscript Report of Captain Don Antonio del Rio: Followed by Teatro Critico Americano; or, A Critical Investigation and Research into the History of the Americans, by Doctor Paul Felix Cabrera, of the City of New Guatemala, Londres: Henry Berthoud ed., 1822.

Schele, Linda y Mary Miller. The blood of Kings: dynasty and ritual in Maya art. Nueva York: George Braziller, 1992.

Schnapp, Alain (Ed.), World Antiquarianism: Comparative Perspectives, Los Angeles: The Getty Research Institute, 2013.

Todorov, Tzvetan. Las morales de la historia. Barcelona: Paidós, 1993.

Von Hagen, Víctor. F. Catherwood, architect-explorer of two worlds. Barre: Barre Publishers, 1968.

. Explorador maya. John Lloyd Stephensy las ciudades perdidas de América central y Yucatán. Buenos Aires: Librería Hachette, 1957.

Von Kugelgen, Helga. “El indio: ¿Bárbaro y/o buen salvaje?”. En La imagen del indio en la Europa moderna, AA.VV. Sevilla: Consejo Superior de Investigaciones Científicas, 1990.

Waldeck, Jean-Frederic, Voyage pittoresque et archéologique dans la province d' Yucatan pendant les années 1834 et 1836, París: Bellizard Dufour et cie, 1838. 